\title{
Forest Contribution to Climate Change Mitigation: Management Oriented to Carbon Capture and Storage
}

\author{
Leonel J.R. Nunes ${ }^{1, *(1)}$, Catarina I.R. Meireles ${ }^{1}\left(\mathbb{D}\right.$, , Carlos J. Pinto Gomes ${ }^{1,2}$ and \\ Nuno M.C. Almeida Ribeiro 1,3 (D) \\ 1 ICAAM - Instituto de Ciências Agrárias e Ambientais Mediterrânicas, Universidade de Évora, \\ 7000-083 Évora, Portugal; cmeireles@uevora.pt (C.I.R.M.); cpgomes@uevora.pt (C.J.P.G.); \\ nmcar@uevora.pt (N.M.C.A.R.) \\ 2 Departamento da Paisagem, Ambiente e Ordenamento, Universidade de Évora, 7000-671 Évora, Portugal \\ 3 Departamento de Fitotecnia, Universidade de Évora, 7000-083 Évora, Portugal \\ * Correspondence: d39529@alunos.uevora.pt; Tel.: +351-266-745-334
}

Received: 3 December 2019; Accepted: 25 January 2020; Published: 27 January 2020

\begin{abstract}
Today, climate change is assumed by many researchers and scholars as a certainty and is presented as the biggest challenge humanity has ever faced. It is commonly accepted that anthropogenic greenhouse gas emissions are the main cause that is accelerating the process. Therefore, it is urgent to find solutions to mitigate climate change, mainly because the intense effects have already been felt, in many cases in the form of the occurrence of extremely violent weather events. Forests are undoubtedly one of the most effective and easiest ways to provide the function of carbon sinks. However, it is essential and convenient to analyze the permanence time of this carbon in forests, because this permanence time depends directly on the forest management model used. This article aims to analyze forest management models from the perspective of carbon residence time in temperate forests, dividing the models into three types, namely carbon conservation models, carbon storage models, and carbon substitution models, according to their ability to contribute to functioning as carbon sinks, thereby contributing to the mitigation of climate change.
\end{abstract}

Keywords: forest management; climate change; carbon sinks; carbon cycle

\section{Introduction}

Mankind is currently facing one of the greatest challenges it has ever faced, and must be prepared to efficiently solve and adapt to the problem, because even if organized in an integrated and global manner, the solution will not be immediate [1-3]. Climate change is a reality which is assumed almost unanimously by the scientific community, but also by the majority of the general population who, even without understanding the technical and scientific components associated with the phenomena, feel the implications and changes in their daily lives [4-6]. An example of these situations is the occurrence of extreme weather phenomena, in particular, concerning forest environments, which have a direct consequence by increasing the occurrence of rural fires and changing environmental conditions that lead to the proliferation of exotic forest species that could present an invasive behavior due to a faster adaptation to the new climatic parameters [7-10].

Assuming that an increasing concentration of $\mathrm{CO}_{2}$ in the atmosphere is the main cause of climate change acceleration, without discussing the origin of this $\mathrm{CO}_{2}$ (Figure 1), it seems clear that the first steps to mitigate the changes are any that can somehow reduce this $\mathrm{CO}_{2}$ concentration [11-14]. However, increasing concentration of $\mathrm{CO}_{2}$ in the atmosphere can be attributed to anthropic activity in the increments of $7.8 \pm 0.8{\mathrm{PgC} \mathrm{yr}^{-1}}^{-1}$ and $1.1 \pm 0.8{\mathrm{PgC} \mathrm{yr}^{-1}}^{-1}$, respectively, associated with fossil fuel use and land use change [15]. In other words, it is a set of all the measures that are implemented to have 
$\mathrm{CO}_{2}$ sequestered from the atmosphere (Figure 2), but at the same time stored for as long as possible, somewhat delaying the natural carbon cycle [16-18].

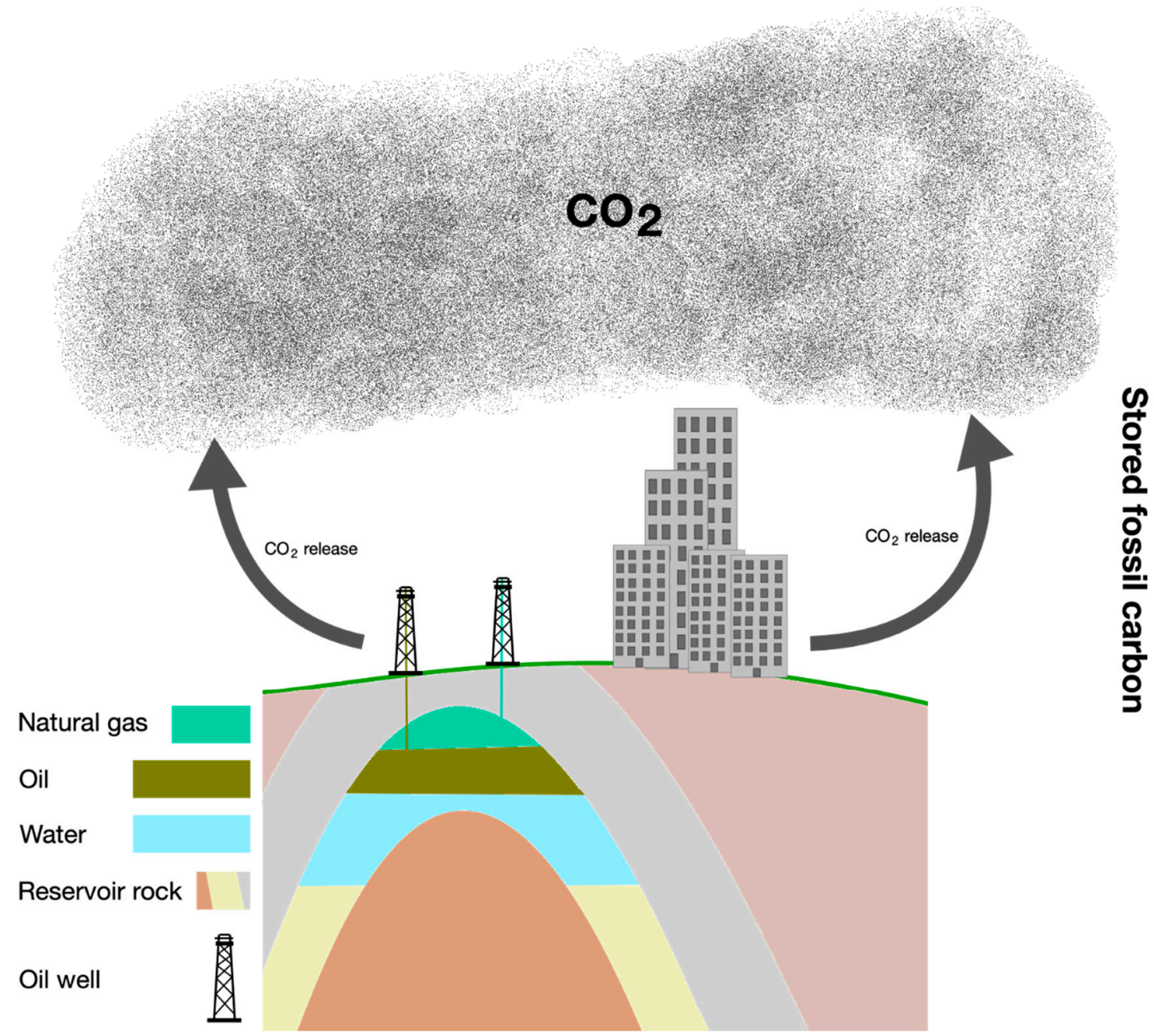

Figure 1. The release of carbon sequestered and stored in the distant past is most likely the leading cause of accelerating climate change. The increasing use of fossil fuels since the period of the industrial revolution is, on the one hand, the basis of societal development as it has made available accessible energy sources, but, on the other hand, it has contributed greatly to pollution and to the increased concentration of $\mathrm{CO}_{2}$ in the atmosphere.

A process, activity, or tool that contributes to $\mathrm{CO}_{2}$ removal from the atmosphere and to storage for a certain period of time is known as a carbon sink. This storage occurs mainly in oceans, soils, and forests, where organisms capture carbon and release oxygen into the atmosphere $[19,20]$. The balance between $\mathrm{CO}_{2}$ captured by forests through photosynthesis is $14.1 \mathrm{PgC} \mathrm{yr}^{-1}$ and the $\mathrm{CO}_{2}$ released through respiration and forest fires is $11.6 \mathrm{PgC} \mathrm{yr}^{-1}$, representing a positive balance of capture and storage [15]. Carbon sinks work like a drain, and unlike sources that emit more carbon than they absorb, they absorb more carbon than they emit. Because it is a natural and environmentally friendly process, human actions have been negatively interfering [21], because burning of fossil fuels, as well as different land uses associated with deforestation and burning, are the main causes of the increase in $\mathrm{CO}_{2}$ levels in the atmosphere. This destruction consequently makes storage more difficult [22]. 


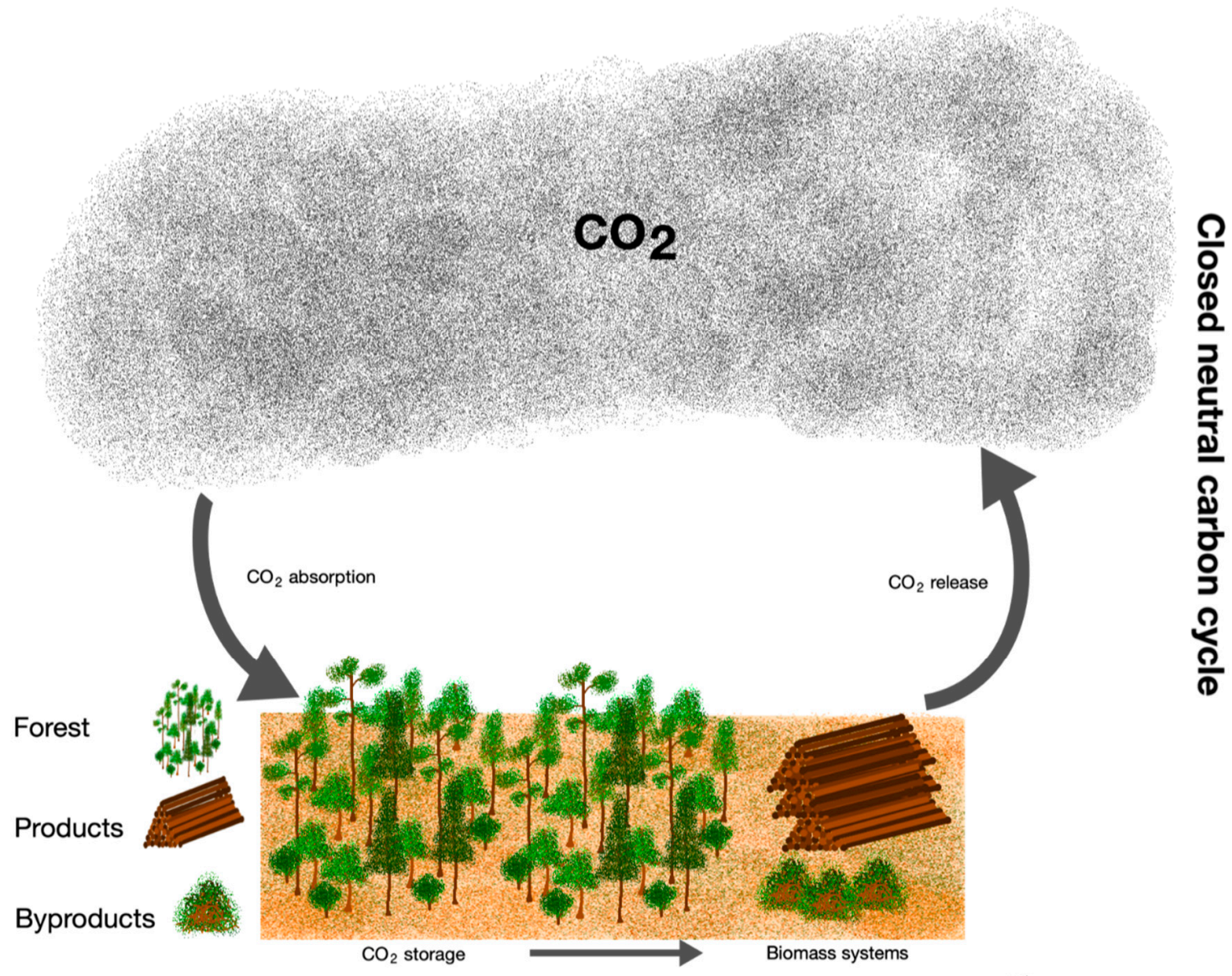

Figure 2. Forests are able to create their own carbon cycle, as trees and plants in general, take $\mathrm{CO}_{2}$ out of the atmosphere and use it to create their own organic matter, along with water and sun energy, through photosynthesis. It is this process that allows the use of biomass energy to be considered carbon neutral, as it is considered that the carbon emitted is only that which the plant has absorbed and stored during its lifetime.

In this perspective, forests present themselves as a potential solution, as they can effectively contribute to $\mathrm{CO}_{2}$ capture and sequestration over different time periods [23]. These periods are greater the longer the longevity of the forest species used, but also totally dependent on the intended purpose for the forest [24], that is, whether short rotation periods are used, as in the case of energy crops, or long rotation periods are used, as in the case of forests intended for the production of timber for construction or shipbuilding [25,26].

In 1997, the Kyoto Protocol suggested that the absorption of carbon dioxide by trees and soil is as valid as reducing $\mathrm{CO}_{2}$ emissions from burning fossil fuels [19]. As a result, trees, other plants, and soil were given great importance as temporary carbon sinks emitted into the atmosphere by burning fossil fuels [27]. However, there is a movement against these carbon sinks because their effect cannot be accurately measured, especially in forests as trees absorb different amounts of carbon and the carbon movement in soils is unknown $[28,29]$.

In addition, there is a problem of interests. Land used for carbon sink projects requires legal agreements that prevent land use for many years [30]. In this way land is used to generate emission rights so that the most polluting countries and industries continue to pollute while communities are unable to meet their needs [31,32].

From this point of view, projects involving reforestation and intensive planting of new forests have been emerging all over the world as they are presented as simple measures to implement $[20,33,34]$. Examples are the reforestation megaprojects being carried out in Africa or India [35-39]. For example, 
the green wall that is being erected in Africa, made of trees, to prevent the advance of the Sahara Desert. It is the $15 \mathrm{~km}$ wide and $7775 \mathrm{~km}$ long "Great Green Wall" across the African continent from Mauritania to Djibouti, with the aim of halting the advancement of the desert, improving the management of natural resources, and fighting poverty [40].

However, many other projects, perhaps less well-publicized, are also being implemented in several other countries, where they are also expected to contribute to climate change mitigation [41-43]. For example, the Cape Verdean government and FAO signed in 2017, a five million euro agreement for the European funding of the project entitled "Strengthening the Capacities and Resilience of the Forest Sector in Cape Verde". The project is to be implemented and financed by FAO with 133,000 euros, and carried out on the islands of Boa Vista, Fogo, and Santiago. The main objective is to increase resilience and strengthen the country's adaptive capacity in view of the additional risks caused by climate change, such as desertification and land degradation [44].

Capture and sequestration of atmospheric $\mathrm{CO}_{2}$ by forests also present differences, because depending on the type of forest development implemented, the results obtained concerning carbon quantity and permanence time vary, and can lead to the achievement of different objectives $[45,46]$.

The main objective of this review article is to analyze different management models applied to temperate forests, defined by their ability to capture and store carbon, but most importantly, for how long this carbon can be stored. Here, the models that are analyzed generically refer to the possibilities of land occupation with forest aptitude, but also are extensible to soils with other occupations, namely old agricultural soils, bushlands, and pastures. In this way, the potential contribution of forests to climate change mitigation is also analyzed.

\section{The Global Carbon Balance}

Although weather has changed throughout the history of the earth, in all time scales, it is clear that the current changes have some distinct aspects. For example, currently, the observed concentration of carbon dioxide in the atmosphere far exceeds the natural range of the last 650,000 years, reaching a record $415 \mathrm{ppm}$, an increase of about $100 \mathrm{ppm}$ from the period prior to the industrial revolution [47]. Another distinct aspect of current climate change is its origin, unlike in the past, where climate change has resulted from natural phenomena, while most current climate change, particularly in the last 50 years, is attributed to human activities [48].

The main evidence of this current climate change is global warming, which has been detected in rising global average air and ocean temperatures, widespread melting of snow and ice, and rising sea levels, and which can no longer be denied $[49,50]$. Currently, the average global surface temperatures are at their highest as compared with at least five centuries. The global average surface temperature has increased by about $0.74{ }^{\circ} \mathrm{C}$ over the last hundred years. If this is no significant action concerning this warming, a very unusual climate is expected during this century which could present, for example, an average increase in global temperature from $2{ }^{\circ} \mathrm{C}$ to $5.8^{\circ} \mathrm{C}$, as reported in 2007 , in the Fourth Report of the Intergovernmental Panel on Climate Change (IPCC) [51,52].

The concentration of atmospheric $\mathrm{CO}_{2}$ has been measured directly and systematically in Mauna Loa (Hawaii, USA) since 1957 [53,54]. For periods prior to this date, this concentration can be calculated by analyzing the atmospheric composition of bubbles of trapped air in the ice of the poles [55-57], taking into account the fact that each bubble is composed of air of different ages and that the deepest ice retains older information (due to the progressive accumulation of ice) [58]. In recent years, a new set of satellites has been launched aimed at quantifying $\mathrm{CO}_{2}$ in the atmospheric column, GOSAT and OCO-2, allowing global and continuous monitoring of flows and concentrations of $\mathrm{CO}_{2}$ with moderate spatial resolution [59-62].

The Global Carbon Project (GCP), implemented in 2001, is a project that periodically documents the evolution of anthropogenic $\mathrm{CO}_{2}$ emissions, as well as $\mathrm{CO}_{2}$ flows in oceanic and terrestrial reservoirs [63] . GCP analyses are limited to the final decades of the twentieth century, for which data obtained through direct observations are available. For earlier periods, the only existing records come from air trapped 
in the polar ice caps [64]. However, the calculation of fluxes present in the terrestrial carbon balance for these periods presents great uncertainty [65].

$\mathrm{CO}_{2}$ emissions from fossil fuel combustion and industry, fossil fuel emissions (FFE), are usually based on energy statistics and cement production data from different organizations, e.g., Carbon Dioxide Information Analysis Center (CDIAC), International Energy Agency (IEA), and United States Department of Energy (DoE), with CDIAC estimates being the only ones providing data since 1751 [66-68]. Emissions from land use and land cover change (LULCC) have been dominated by deforestation in recent decades [69]. They are generally based on statistical or satellite data (where available) of land use and land cover changes and are calculated using various types of models, these data currently being combined with information on fires (related to human intervention), usually from satellites [70,71].

Observations of ocean $\mathrm{CO}_{2}$ fluxes (SOCEAN) have been made from the 1970s onwards by measuring the surface $\mathrm{CO}_{2}$ pressure $\left(\mathrm{pCO}_{2}\right)$ [72-74]. However, these observations correspond to point measurements in the oceans, which means that global sequestration is not necessarily known. It is for this reason that annual anomalies and trends in the global ocean sink are usually estimated using ocean models (as in the GCP, for example) [75].

With respect to $\mathrm{CO}_{2}$ fluxes in terrestrial ecosystems, the only direct measurements available are point data of turbulent vertical gas flows in the atmosphere (eddy covariance flux), and these data are available for long periods and homogeneous topography locations $[76,77]$. These measurements have been in existence for a few decades (since the 1990s systematically) and are organized in continental and global networks such as FLUXNET, which enables global and regional assessment of $\mathrm{CO}_{2}$ exchange [78-80]. FLUXNET is a network of meteorological sensors measuring atmospheric state variables, such as temperature, humidity, wind speed, rainfall, and atmospheric carbon dioxide, on a continuous basis, and serves to predict weather, climate, and the cycling of carbon and water [81].

\section{Carbon Flows in Terrestrial Ecosystems}

Disruptions in the global carbon cycle are framed within a broader context as the "global environmental exchange", which in many ways ameliorates the functioning of the planet and includes various closely related phenomena and processes [82]. A global change is defined by the types of phenomena involved which include (a) One that alters the fluid layers of the Earth systems (the atmosphere or the ocean), and therefore is experienced on a planetary scale and (b) one that occurs in discrete but widely distributed places that constitute a global exchange [82-84]. Examples of the first phenomena include changes in the composition of the atmosphere (e.g., increases in the concentration of carbon dioxide and methane), climate change, the destruction of the ozone layer in the stratosphere, and an increase of ultraviolet radiation. Examples of the second type of phenomena include loss of biodiversity, exchanges in its use (e.g., the destruction of forests for agricultural use), changes in atmospheric chemistry (e.g., the acidic cloud and the increase of ozone concentration in the troposphere), and biological invasions [85].

The common denominator of all the components of the global environmental exchange is human activity, which has acquired enormous proportions in relation to the energy and material flows at the global level [86]. The disruptions in the global carbon cycle have severe repercussions on the climate of the planet due to the properties of $\mathrm{CO}_{2}$ and methane as greenhouse gases, such as a major concentration in the atmospheric atmosphere and the highest global average temperature of the planet [87].

To understand the factors that influence LULCC, one must consider the different biogeophysical, biogeochemical, and ecological processes that occur at different time scales and affect carbon flows in terrestrial ecosystems [88]. At short time scales, ecosystems exchange energy, water, and other chemical compounds (Figure 3), and these exchanges are regulated by physical and ecological processes on a daily basis or on a seasonal basis $[89,90]$. Energy and water exchanges are mostly influenced by vegetation or soil characteristics, such as albedo, which regulates the amounts of solar energy absorbed and reflected by the earth's surface, or soil water availability, which regulates the hydrological cycle and latent heat fluxes [91]. 


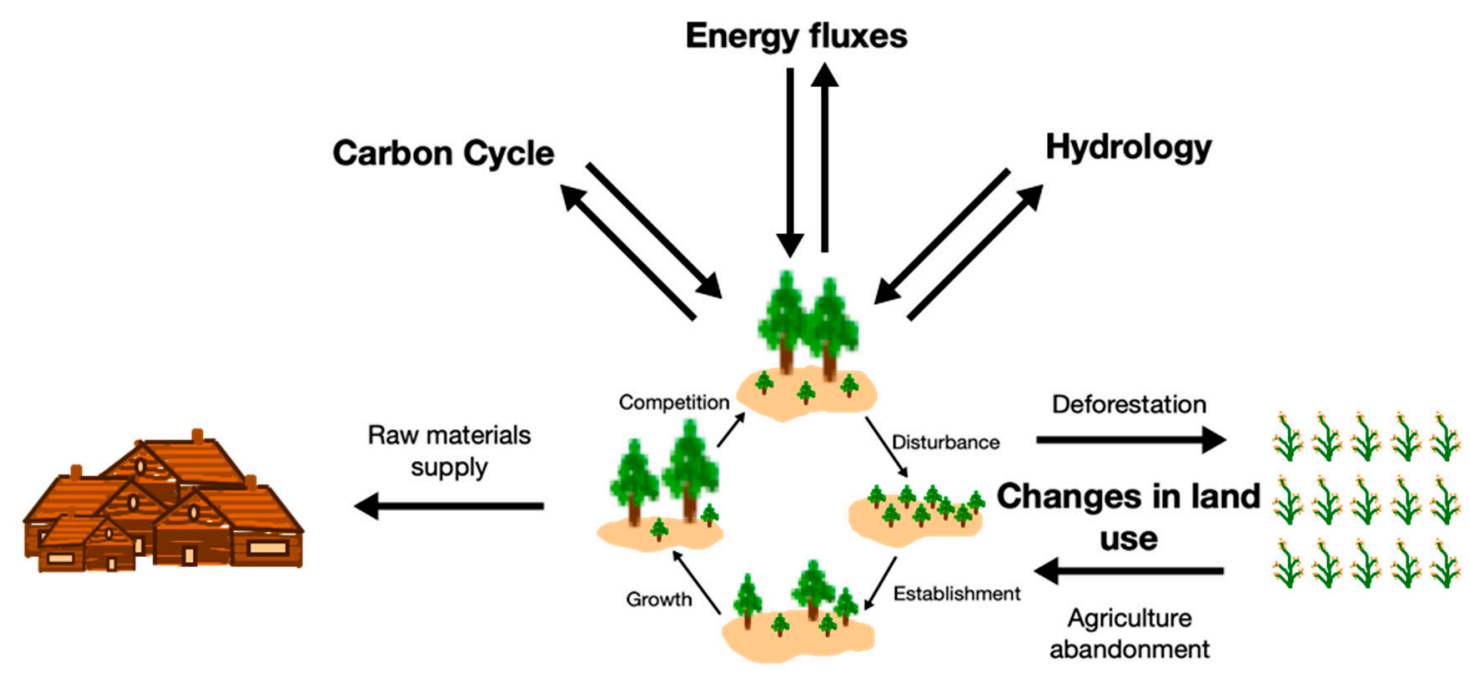

Forest dynamics

Figure 3. Schematic representation of the main biophysical and biogeochemical processes in terrestrial ecosystems (adapted from [89]).

General mechanisms operating jointly are considered to exist, but on different scales of time. In the broad range (hundreds of millions of years), the carbonate-silicate geochemical cycle operates as a concentration regulator [92]. In this cycle, atmospheric $\mathrm{CO}_{2}$ dissolves in rainwater and forms carbonic acid that reacts with the minerals exposed on the earth's surface, generating what is known as weathering of the rock [93]. The rivers surround the products that are discarded by the ocean. In the ocean, calcium carbonate is formed. This is deposited in the marine sediments through the process of subduction between the low crust of the Tierra. In this process, elements are reincorporated into the primary minerals of the rocks and the carbon returns to the atmosphere as $\mathrm{CO}_{2}$ by the volcanic and hydrothermal emissions. This geochemical cycle has helped to maintain atmospheric $\mathrm{CO}_{2}$ concentration by a $1 \%$ decrease over the last 100 million years. However, annual carbon flows are relatively small [92,94].

Radiative and hydrological processes, therefore, play a fundamental role in the functioning of terrestrial ecosystems (through variables such as temperature, precipitation, evapotranspiration, and soil water profile) [95]. Momentary changes are associated with wind-borne energy, whose behavior influences soil and plant evapotranspiration [96]. $\mathrm{CO}_{2}$ flows are mostly related to photosynthesis, respiration, and decomposition of organic matter, and are largely conditioned by other physical processes. Examples of factors influencing the various processes mentioned above are the seasonal variability of solar radiation, local hydrology, nutrient absorption, and mineralization, or vegetation phenology and resource allocation [97].

The ability of terrestrial ecosystems to function as carbon sinks depends, to an important extent, on the "fertilization effect" due to the increase in the concentration of carbon dioxide in the atmosphere and the deposition of atmospheric nitrogen, which is emitted in excess for various human activities [98]. Fertilization by $\mathrm{CO}_{2}$ is possible, and its current atmospheric concentration limits the productive capacity of plants [99]. There is evidence that the effect of fertilization increases the growth of plants under natural conditions, however not to the extent that physiological studies of individual plants and controlled conditions suggest [100].

As schematized in Figure 3, over a year, ecological processes affect the structure and composition of ecosystems, which in turn control short-term functioning, such as competition between different vegetation types, nutrient deposition, and regime disorders (e.g., fires, droughts, and pests) [101]. Human activities also interfere with the structure and functioning of terrestrial ecosystems through LULCC, soil and forest management, or the addition of nutrients to ecosystems [102]. 
As represented in the figure, ecosystems are dynamic and their composition and structure changes over time. There are periodic disturbances such as fires, hurricanes, droughts, floods, and pests that substantially change grasslands, forests, estuaries, mangroves, and other communities. These events are known as disturbance regimes and change from region to region depending on weather conditions. Currently, the main disturbance regime is human activities. Wood harvesting from forests, roving crop systems, and other activities transform ecosystems into successive states.

Carbon is found in the atmosphere, the biosphere, the oceans and the sediments [103]. Plants use $\mathrm{CO}_{2}$ from the atmosphere and convert it into carbohydrates and in this way, much is stored in forests and soil. In the sea, many organisms use carbon to form their external skeletons and their shells [104]. Carbon returns to the atmosphere through the respiration of organisms, organic decomposition, combustion, and volcanic eruptions [74]. The other chemical elements have similar cycles [105].

Water is the most abundant molecule on the surface of the planet Earth. It is the only molecule that can be found naturally in a solid, liquid, and gaseous state and is essential to all life on Earth [53]. The properties of water provide a perfect medium for biological reactions that occur within cells, from the ability to store energy through photosynthesis, to energy consumption through respiration [106]. The water that evaporates from the oceans with the energy of the sun is transported by the circulation of winds around the planet [107]. When wind is rising, following the contours of the mountains, the wind cools and transforms into rain providing moisture to forests, jungles, grasslands, and thickets and suppling streams, rivers, lakes, groundwater, and finally returns to the sea [108]. In this long way, water is absorbed by plants and consumed by animals that require it since it constitutes between $55 \%$ and $80 \%$ of living beings [109].

Living things require energy to perform their basic growth, reproduction, and survival activities. Plants are the primary producers that transform the sun's energy into chemical energy through photosynthesis. First the chlorophyll molecule absorbs the energy of light and divides the water molecules into hydrogen and oxygen [110]. As a second step, carbon dioxide is transformed into carbohydrates (sugars), that is, into larger molecules of carbon, hydrogen, and oxygen [111]. Herbivores, as primary consumers, feed on plants and obtain nutrients and energy from them, which in turn are passed to carnivores and from these to decomposers [71]. The flow of energy through living beings is known as the trophic chain or food chain and each of the levels through which it passes, is known as a trophic level [59].

\section{Forest Management based on Carbon Capture and Sequestration Capacity}

\subsection{Carbon Conservation Model}

As noted above, the process of carbon capture and sequestration involves removing carbon dioxide from the atmosphere. This process occurs mainly in oceans, forests, and other places where organisms, through photosynthesis, capture carbon and release oxygen into the atmosphere. It is the capture and safe storage of carbon dioxide $\left(\mathrm{CO}_{2}\right)$ that prevents its emission and permanence in the atmosphere [112,113].

Figure 4 is a schematic representation of this type of model, which shows the major interactions that contribute to a forest management trend in which carbon concentration is conserved in the forest [114]. Theoretically, this model does not contribute to the reduction of atmospheric carbon, but also does not contribute to increasing its amount [115]. Concerning the carbon content, this model is considered neutral [116]. However, this claim presents some controversy for several authors [117-124], in particular, whether the primary mitigation value of forests is in instantaneous and short-term flux rates and product substitution or stock longevity [120,122,125-129].

Examples of measures projected to increase the conservation of a larger carbon content include increasing coppice rotation periods, avoiding damage to trees during forestry operations, reducing logging residues by applying soil conservation techniques, and using wood in a more carbon efficient way [130]. 
An example of this forest management model is found in the Eucalyptus spp. planted forests for the pulp and paper industry supply [131-133], but other examples are found in Acacia spp. or Salix spp. plantations for energy production, where the species used have rotation periods shorter than 15 years, depending mainly on the location and on the species characteristics [132,134]. This type of forest with shorter rotation periods conserves carbon content. In reality, this system only allows the carbon returned by industry to the cycle to be captured and stored, and does not allow a positive balance towards carbon sequestration for long periods [135].
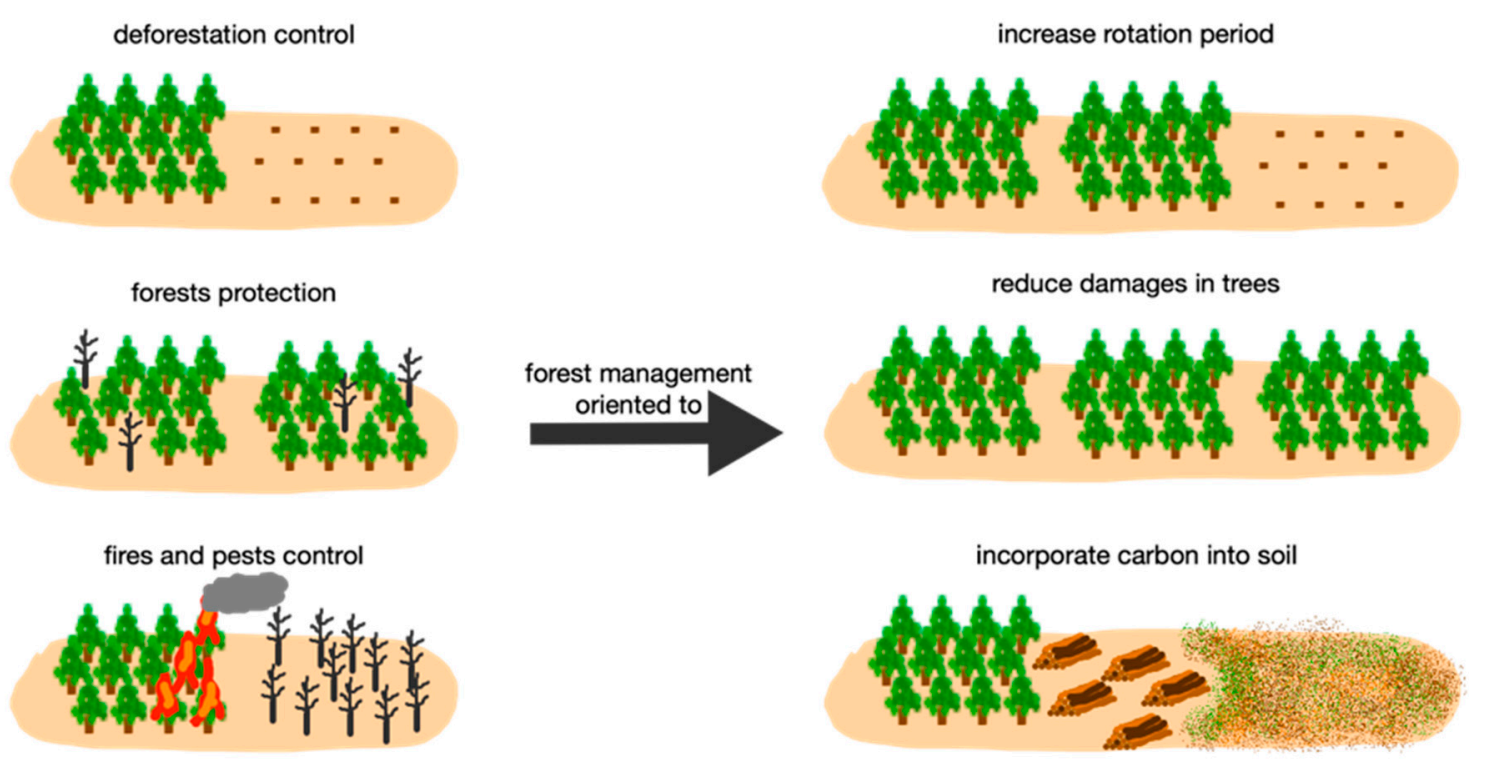

Figure 4. Forest management model for carbon conservation (adapted from [136]).

\subsection{Carbon Storage Model}

Figure 5 shows a schematic representation of the forest management model for carbon storage. The objective of this model is to increase the amount of carbon in the forest vegetation and soil, increasing the surface or carbon content of biomass in natural and planted forests by increasing storage in durable wood materials [137].

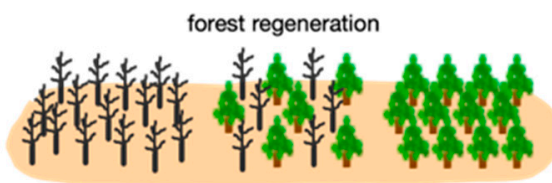

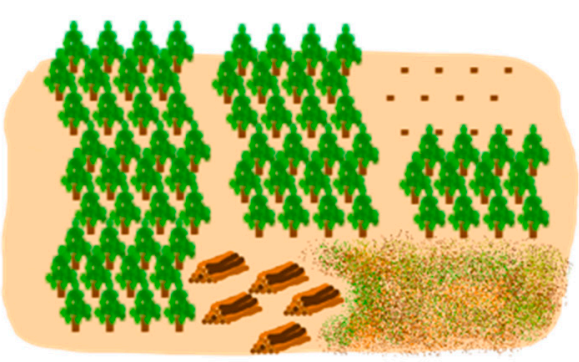

Starting from the Carbon Conservation Model

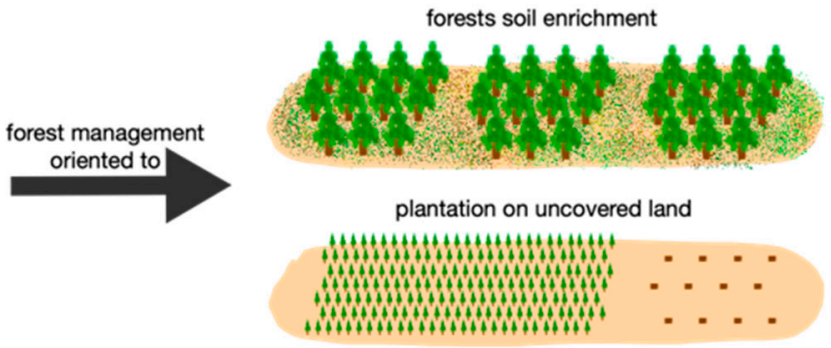

increase demand for timber

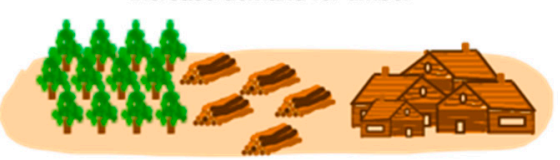

Figure 5. Forest management model for carbon storage (adapted from [136]). 
To increase carbon storage in vegetation and soil, it is necessary to protect secondary forests and other degraded forest areas, those which have carbon content values below the maximum possible in both plants and soil, by carrying out regeneration and soil enrichment [138].

Reforestation of uncovered land together with the promotion of natural or artificial regeneration of secondary forests, and also increasing forest cover on agricultural land or pastures, are measures that contribute to increasing the amount of sequestered carbon [139].

In the case of timber products, carbon stocks can increase due to a higher demand for timber products, which is occurring at a faster rate than the rate at which wood deteriorates and due to the extension of the durability of timber products [140]. An example of this model of forest management can be found in the planted forests of Pinus spp., the most common species being Pinus pinaster, Pinus elliottii, or the Pinus caribaea var. hondurensis, used for the supply of resin gum for the chemical industry [141], but others can be found as well, such as, for example, Hevea brasiliensis, the rubber tree.

Forests with longer rotation periods of 15 to 25 years, where the replacement cycle of trees is longer that one used for energy or the pulp and paper industry, capture and sequester carbon fixation over longer periods [142].

\subsection{Carbon Substitution Model}

The main objective of this management model, as shown in Figure 6, is to increase the amount of carbon transferred from forest biomass to other products, usually derived directly or indirectly from fossil fuels, such as biofuels or building materials, instead of using fossil fuel-derived energy or cement industry-derived products [143]. This perspective presupposes the extension of the use of forests to supply raw materials and fuels. This can be achieved by the establishment of new forests or by increasing the growth rates of already existing forests [144]. However, the fact that wood products also create emissions should be taken into account, in particular the production of biofuels must be deeply analyzed once it contributes mostly carbon storage problems related with deforestation for land use [145].

This type of management model, i.e., forests where energy crops are settled on land without any sort of cover or with non-arboreous cover, can generate an increment in the total amount of carbon captured and sequestered in that area. Furthermore, biomass used as fuel replaces an equivalent amount of fuel with fossil origin, creating an effective carbon uptake rate in unburnt fossil fuels, known as offset emissions [146].

An example of this forest management model is when this management is implemented from the perspective of circular economy, where the byproducts resulting from forestry operations are converted into biomass-derived fuels, such as wood pellets or biochar and, then, used in substitution of fossil fuels [146]. This management model allows the captured and sequestered carbon to replace an equivalent amount of carbon of fossil origin [147], while maintaining the larger amount of carbon captured and stored for much longer periods, than in those models described previously [148].

Another form that can be considered inside this management model scheme are the Quercus suber plantations used in the supply of raw materials for the cork industry [141]. This type of forest with extremely long rotation periods, where the replacement cycle of trees is very long, allows the accumulated carbon to be captured and sequestered, allowing a positive balance towards carbon fixation over long periods $[142,149,150]$, at the same time that it releases byproducts that can be included into a circular economy procedure [151]. In these forests, trees can present a rotation period much higher than 25 years, as is the case of the above mentioned Quercus suber for cork production, where the economic viability can be reached only after 25 years when the first cork is extraction, but the profit only arrives after the third cork extraction, 18 years after, maintaining this capacity cyclically each 9 years and during almost 200 years [152]. 

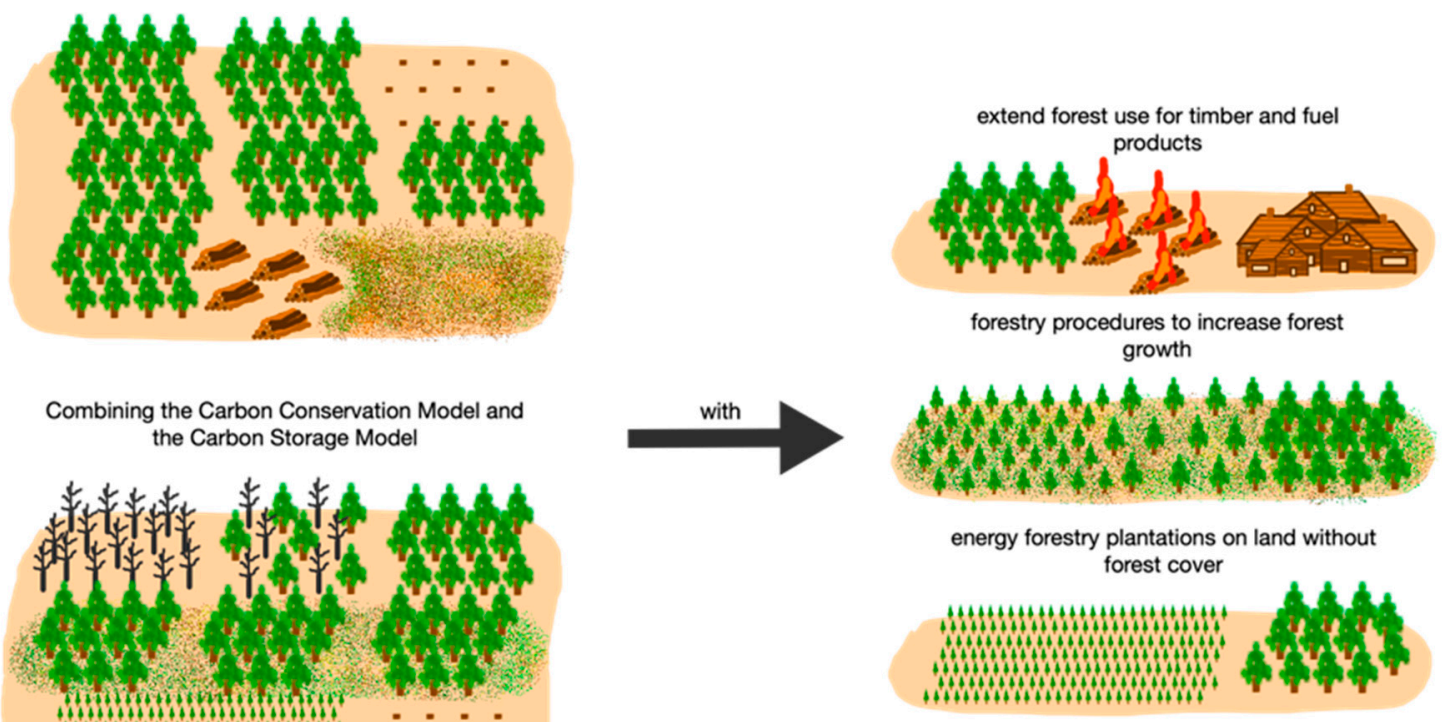

Combining the Carbon Conservation Model and the Carbon Storage Model

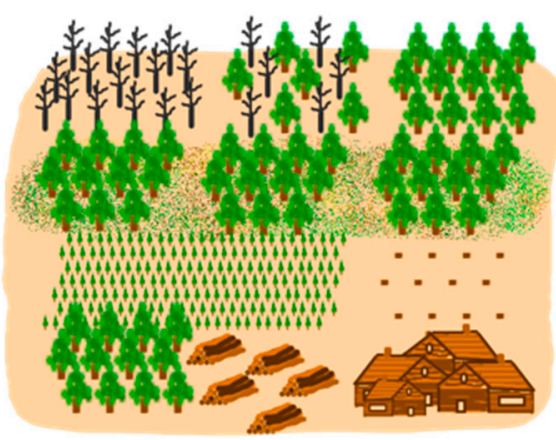

replace fossil fuels for biomass derived fuels

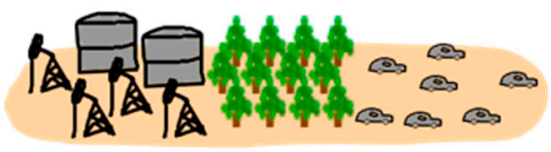

increase the use of short rotation coppices for energy production
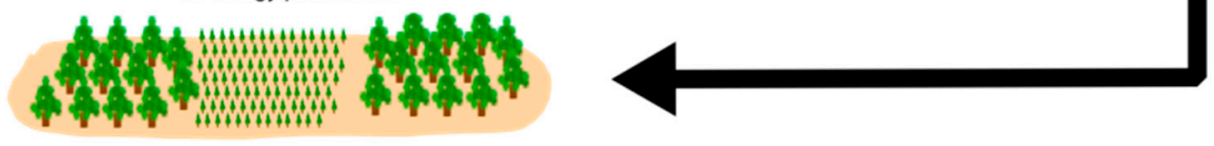

forest management oriented to

increase the ocupation of non used land with forest crops

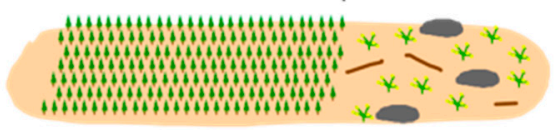

Figure 6. Forest management model for carbon substitution (adapted from [136]).

\section{Discussion and Conclusions}

It is commonly known that forests are a very important part of the carbon balance. A large part of the terrestrial carbon with organic origin is captured and sequestered in the biomass generated and in soil. As a main result, alterations in the $\mathrm{CO}_{2}$ balance in forest ecosystems occur, which are due to changes in use or changes in the management model, with significant impacts on the concentration of atmospheric $\mathrm{CO}_{2}$.

Forest management is defined as the use of forest resources through sustainable techniques, preserving species and ecosystems. In the case of industrial exploitation, this management can be done through productive rotation, in which the mature trees are cut, while the young ones grow to be cut in the future, while new seedlings are planted, in a continuous cycle of extraction and preservation.

The interactions between the forest management models described here are outlined in Figure 7. Each one of the models is analyzed from the perspective of the intensity with which different forms of management model can be applied, and the tasks leading to the fulfillment of the intended objectives. Forest management increases the chances of continuing to harness natural resources over the years and reduces the risk of deforestation and forest devastation. 


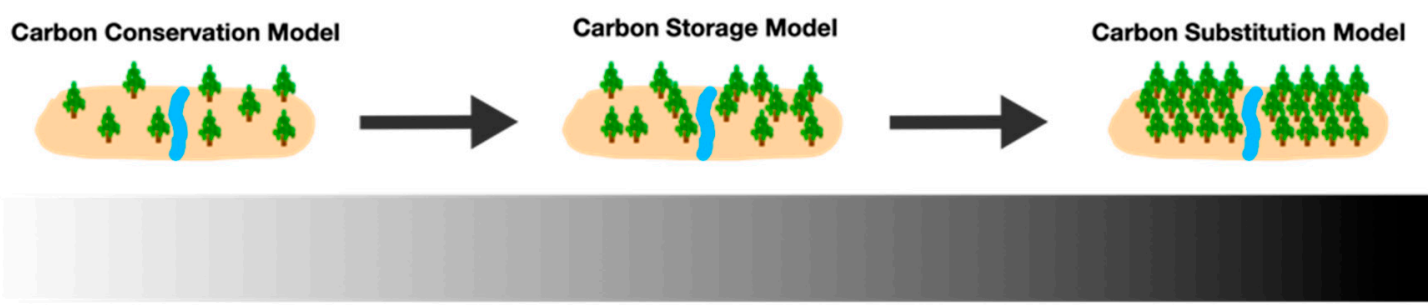

Carbon Sink Capacity

Figure 7. Models of forest management based on carbon flows.

The carbon conservation model is the most common, basic and simplistic model, and the one that normally occupies the largest forest area, even when there is no concrete objective of immediate raw material supply, but rather because forest owners have the short-term perception of earning income. Other models are more complex, including more variables and more mitigation measures used to significantly increase the carbon capture and sequestration rates, and finally, in the last model presented, mitigation measures are used for offsetting emissions [153].

These approaches include the production of raw materials, such as timber and fuels, and also environmental goods and services (Figure 8). Therefore, this must be understood as an opportunity to expand the vision of planning forests as a resource, considering in the planning the inclusion of environmental services for carbon capture, fixation, and storage, in other words, produce the service of a carbon sink that is used to finance the development of new forests.
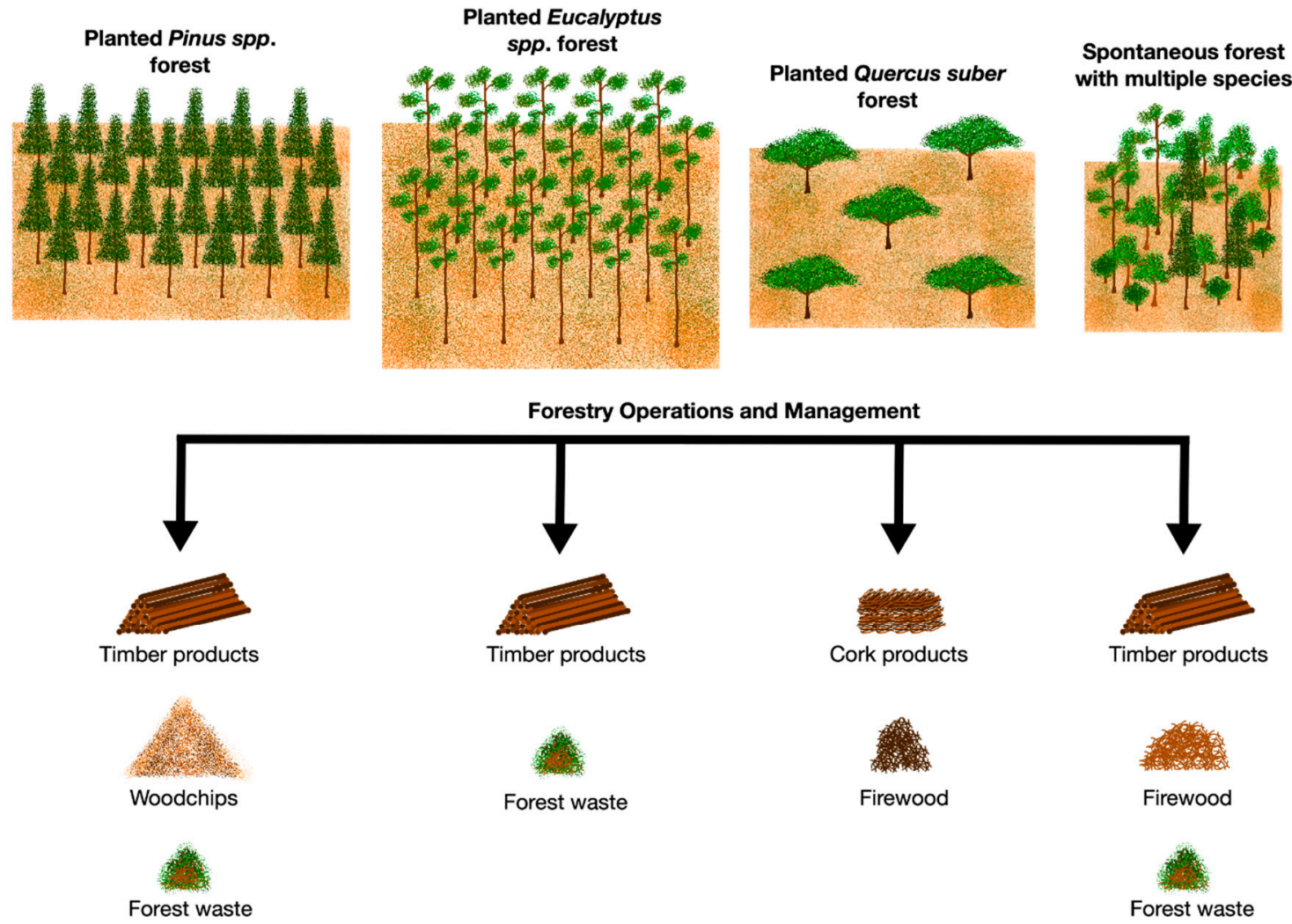

Figure 8. Different types of forest species also provide different types of products. However, in some cases, the products supplied are similar, varying only in quantity and quality. For this reason, the potential economic value varies with the choice made for afforestation.

Trees are generally species with longevity. The cycles of growth and basal metabolism of trees are processes that usually depend directly on climate conditions over time (Figure 9). This is mainly true 
with regards to temperature, precipitation, and solar radiation. Thus, any changes in these factors affect the growth rates of trees, and even the survival of the species, especially when these changes happen too fast, without giving time for forest species to adapt to new climate conditions.

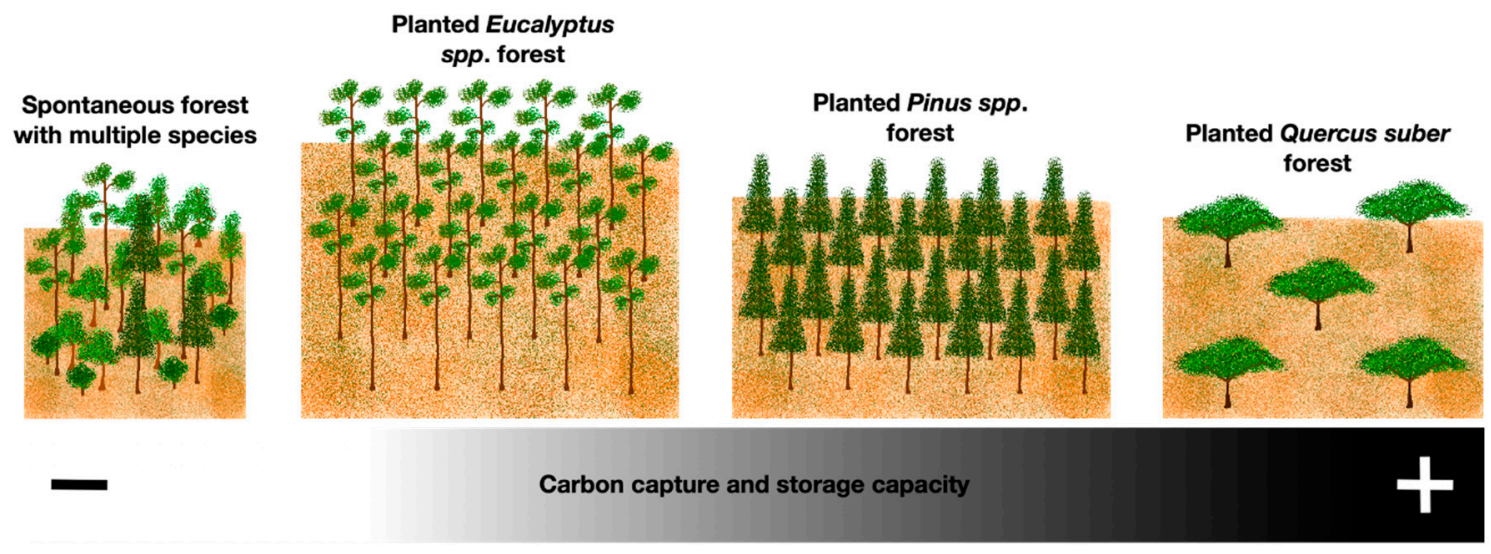

Figure 9. Carbon capture and storage capacity of different forest types.

Figure 10 schematically represents the different examples of forest management models associated with the capacity that each type of model can have in storing carbon over time. As can be seen from the graphs shown, this storage capacity is directly related to the rotation time used. Thus, it is considered that models that use short or medium rotation times, such as the rotation periods associated with Eucalyptus spp. or Pinus spp., have equivalent storage capacities. Planted forests of Quercus spp., or similar species, have a higher carbon storage capacity over the long term, as the rotation periods used can reach many tens, or even hundreds of years. Any of these forest management models have high potential economic returns given the quantity and quality of the products supplied.

It is also possible to relate the risk of fire with the use of these forest management models, as it is understood that the risk of fire decreases in direct proportion to the increment of management and operation activities, namely through cleaning, sanitary thinning, or from cutting down sick or defective trees. Thus, the risk of fire is higher in spontaneously growing forests, as the disorganized growth of several species increases the storage of high fuel loads due to the lack of management, because the poor quality of the products does not allow its monetization $[154,155]$.

Forests, whether in an arctic, temperate, or tropical environment, play a major role in gas exchanges with the atmosphere, as they are the major flows of greenhouse gases. For the most important of all, $\mathrm{CO}_{2}$, forests can be both source and sink. Thus, during the daytime, forests absorb large amounts of $\mathrm{CO}_{2}$. This amount is greater than that released by breathing. Thus, forests play the role of $\mathrm{CO}_{2}$ sinks. Intuitively, mature, old primary forests should absorb a similar amount of $\mathrm{CO}_{2}$ to the forests that can release $\mathrm{CO}_{2}$, thus, achieving a balance. Two hypotheses are suggested to explain this positive balance:

(1) $\mathrm{CO}_{2}$ storage is the response of the forest to climate change and especially to the increase of $\mathrm{CO}_{2}$ concentration in the atmosphere;

(2) The most important forests on the planet are not as mature and old as previously thought, and therefore are still be in a phase of regeneration after disturbances, which has left deep marks in their functioning.

However, if forests store $\mathrm{CO}_{2}$, cutting more than their regeneration capacity (intensive deforestation for agriculture or mining) causes a significant decrease in $\mathrm{CO}_{2}$ storage, and in response, forests become sources of greenhouse gases. When analyzing the balance in a large forest region, it is important to specify which area the balance corresponds to, as an undisturbed forest is an important $\mathrm{CO}_{2}$ sink, but taken together when disturbed forests and destroyed forests are included, and burned, the forest can be a major source of $\mathrm{CO}_{2}$ to the atmosphere. 


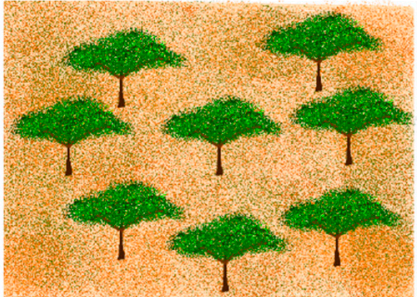

Planted Quercus spp. or other native forest

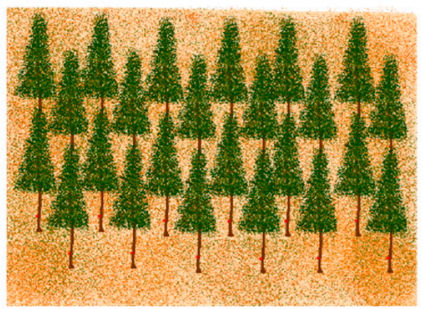

Planted Pinus spp. forest

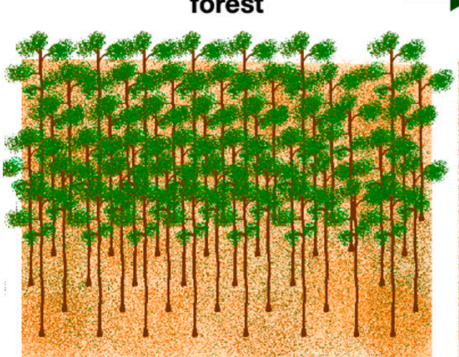

Planted Eucalyptus spp. forest or other short rotation coppices

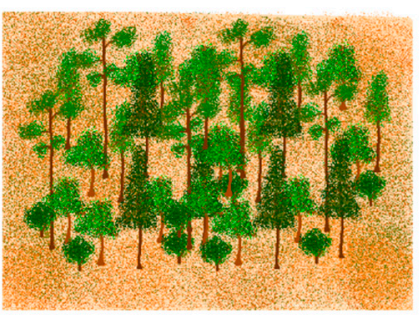

Spontaneous forest with multiple species including invasive and shrub species

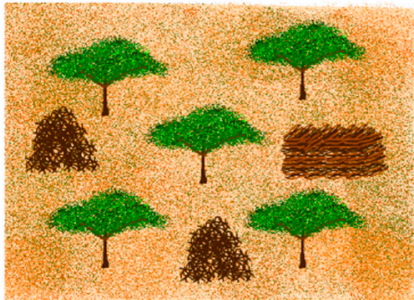

Forest with high profitability with very high quality and added value materials

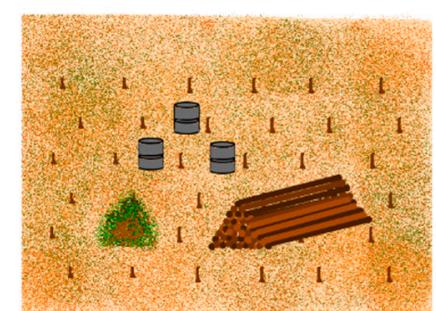

Forest with high profitability combining, e.g., wood and resin collection

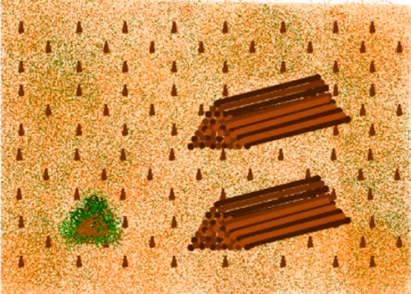

Forest with high profitability due to the large amount of wood produced

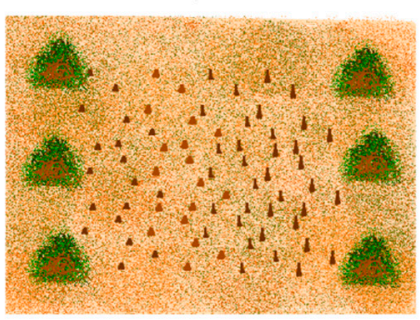

Forest with low profitability because no good quality materials are obtained
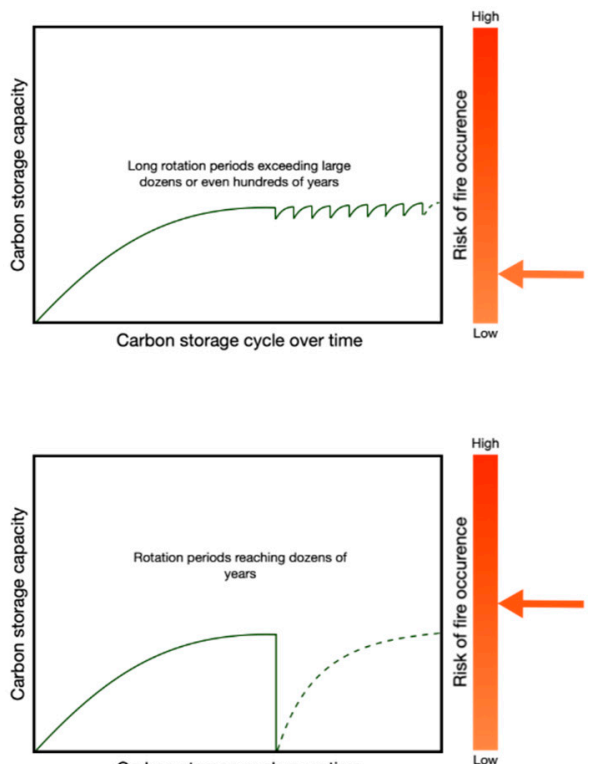

Carbon storage cycle over time

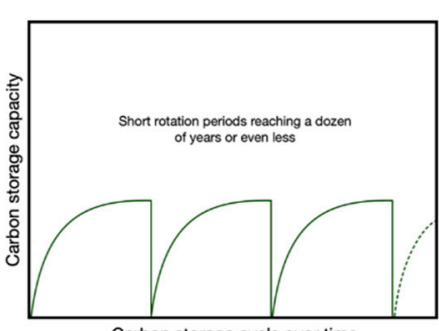

Carbon storage cycle over time

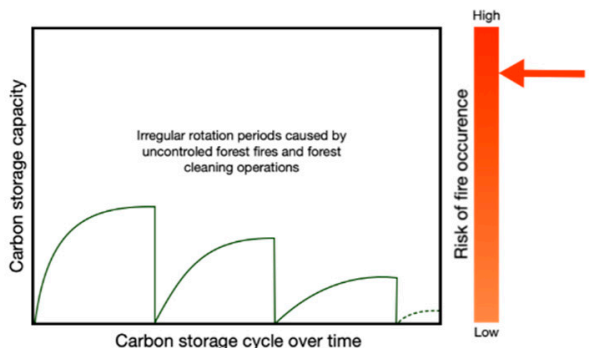

Carbon storage cycle over time
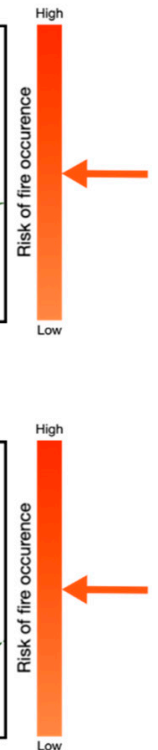

Figure 10. Relationships between different types of forest with potential economic performance, carbon storage capacity, and fire risk. Fire risk is a variable that has to be introduced, as this risk depends on the ability of temperate forests to keep carbon stored for longer periods, but also on the potential interest of forest owners to make a particular type of forest to the detriment of another.

Thus, it is necessary to discover the proper tools needed for native and planted forests in temperate regions to evolve with the new scenario of climate change. A critical phase that must be considered with particular attention is the phase of regeneration and implementation of forests, because young plants are deeply susceptible to and dependent on variations in radiation levels and water availability. This failure in the establishment could jeopardize equally the stability of native and new planted forests.

The idea embedded in the concept of carbon sinks is that tree plantations, through photosynthesis, could offset $\mathrm{CO}_{2}$ emissions by absorbing $\mathrm{CO}_{2}$. Many years ago, Larry Lohmann [156] warned that "the problem is how to calibrate a significant and reliable 'equivalence' between carbon permanently 
sequestered in fossil fuel deposits, transient $\mathrm{CO}_{2}$ in the atmosphere, and carbon sequestered temporarily as result of any particular tree planting or national tree planting program. No one has a clue how to do that. Nor are they likely to have it someday".

It is important to consider that the magnitudes that are currently calculated for carbon sinks will not operate steadily in the future, as all key processes diminish. For example, carbon capture by young forests that grow in agricultural lands diminish as they mature. But it is expected that climate change effects on ecosystems will reduce the capacity of the sinks on a global scale. It is essential to take into account these limitations of the biological systems of the planet and to consider the global carbon balance in the future.

Author Contributions: Conceptualization, L.J.R.N., C.I.R.M., C.J.P.G., and N.M.C.A.R.; methodology, L.J.R.N.; validation, C.I.R.M., C.J.P.G., and N.M.C.A.R.; writing-original draft preparation, L.J.R.N.; writing-review and editing, C.I.R.M., C.J.P.G., and N.M.C.A.R.; supervision, C.I.R.M., C.J.P.G., and N.M.C.A.R. All authors have read and agreed to the published version of the manuscript.

Funding: This research received no external funding.

Acknowledgments: The authors declare no need for further acknowledgements.

Conflicts of Interest: The authors declare no conflict of interest.

\section{References}

1. Senge, P.M.; Smith, B.; Kruschwitz, N.; Laur, J.; Schley, S. The Necessary Revolution: How Individuals and Organizations Are Working Together to Create a Sustainable World; Crown Business: New York, NY, USA, 2008.

2. Hart, S.L. Capitalism at the Crossroads: The Unlimited Business Opportunities in Solving the World's Most Difficult Problems; Pearson Education: New York, NY, USA, 2005.

3. Keohane, R.O.; Victor, D.G. The Regime Complex for Climate Change. Perspect. Polit. 2011, 9, 7-23. [CrossRef]

4. Ziman, J.M. Public Knowledge: An Essay Concerning the Social Dimension of Science; CUP Archive: Cambridge, UK, 1968.

5. Buttel, F.H.; Dickens, P.; Dunlap, R.E.; Gijswijt, A. Sociological theory and the environment: An overview and introduction. In Sociological Theory and the Environment: Classical Foundations, Contemporary Insights; Rowman \& Littlefield Publishers: Lanham, MD, USA, 2002; pp. 3-32.

6. Brulle, R.J.; Dunlap, R.E. Sociology and global climate change. Clim. Chang. Soc. Sociol. Perspect. 2015, 1, $1-31$.

7. Rosenzweig, C.; Iglesias, A.; Yang, X.; Epstein, P.R.; Chivian, E. Climate Change and Extreme Weather Events; Implications for Food Production, Plant Diseases, and Pests. Glob. Chang. Hum. Heal. 2001, 2, 90-104. [CrossRef]

8. Flannigan, M.D.; Krawchuk, M.A.; De Groot, W.J.; Wotton, B.M.; Gowman, L.M. Implications of changing climate for global wildland fire. Int. J. Wildland Fire 2009, 18, 483-507. [CrossRef]

9. Hansen, A.J.; Neilson, R.P.; Dale, V.H.; Flather, C.H.; Iverson, L.R.; Currie, D.J.; Shafer, S.; Cook, R.; Bartlein, P.J. Global change in forests: Responses of species, communities, and biomes: Interactions between climate change and land use are projected to cause large shifts in biodiversity. BioScience 2001, 51, 765-779. [CrossRef]

10. Pautasso, M.; Döring, T.F.; Garbelotto, M.; Pellis, L.; Jeger, M.J. Impacts of climate change on plant diseases-opinions and trends. Eur. J. Plant Pathol. 2012, 133, 295-313. [CrossRef]

11. Schneider, S.H. The greenhouse effect: Science and policy. Science 1989, 243, 771-781. [CrossRef] [PubMed]

12. Fleming, J.R. Fixing the Sky: The Checkered History of Weather and Climate Control; Columbia University Press: New York, NY, USA, 2010.

13. Oreskes, N. The scientific consensus on climate change: How do we know we're not wrong? In Climate Change: What It Means for Us, Our Children, and Our Grandchildren; MIT Press: Cambridge, UK, 2007; pp. 65-99.

14. Yamasaki, A. An Overview of $\mathrm{CO}_{2}$ Mitigation Options for Global Warming-Emphasizing $\mathrm{CO}_{2}$ Sequestration Options. J. Chem. Eng. Jpn. 2003, 36, 361-375. [CrossRef]

15. Finkl, C.W. (Ed.) Carbon cycle. In Encyclopedia of Earth Sciences Series; Springer: Berlin, Germany, 2018.

16. Kellogg, W.W. Climate Change and Society: Consequences Increasing Atmospheric Carbon Dioxide; Routledge: Abingdon, UK, 2019.

17. Seidel, S. Can We Delay a Greenhouse Warming?: The Effectiveness and Feasibility of Options to Slow a Build-up of Carbon Dioxide in the Atmosphere; United States Environmental Protection Agency: Washington, DC, USA, 1983. 
18. Bachu, S. Screening and ranking of sedimentary basins for sequestration of $\mathrm{CO}_{2}$ in geological media in response to climate change. Environ. Earth Sci. 2003, 44, 277-289. [CrossRef]

19. Gorte, R.W. Carbon Sequestration in Forests; DIANE Publishing: Collingdale, PA, USA, 2009.

20. Metz, B.; Davidson, O.; De Coninck, H. Carbon Dioxide Capture and Storage: Special Report of the Intergovernmental Panel on Climate Change; Cambridge University Press: Cambridge, UK, 2005.

21. Perry, D.A.; Oren, R.; Hart, S.C. Forest Ecosystems; JHU Press: Baltimore, MD, USA, 2008.

22. Plasynski, S.I.; Litynski, J.T.; McIlvried, H.G.; Srivastava, R.D. Progress and New Developments in Carbon Capture and Storage. Crit. Rev. Plant Sci. 2009, 28, 123-138. [CrossRef]

23. Shahbazi, A.; Nasab, B.R. Carbon Capture and Storage (CCS) and its Impacts on Climate Change and Global Warming. J. Pet. Environ. Biotechnol. 2016, 7, 291. [CrossRef]

24. Pires, J.C.M.; da Cunha Goncalves, A.L. Bioenergy with Carbon Capture and Storage: Using Natural Resources for Sustainable Development; Academic Press: Cambridge, UK, 2019.

25. Savill, S.P. The Silviculture of Trees Used in British Forestry; CAB International: Wallingford, UK, 1991.

26. Bartlett, D.; Nicolescu, V.-N.; Pyttel, P. Evolution and Perspectives of Coppice Forests in European Countries and South Africa. Available online: Gala.gre.ac.uk/14009/5/14009_BARTLETT_FPS-COST_Coppice_Forests_ Final_2015.pdf (accessed on 27 November 2019).

27. Daniels, T.L. Integrating Forest Carbon Sequestration Into a Cap-and-Trade Program to Reduce Net $\mathrm{CO}_{2}$ Emissions. J. Am. Plan. Assoc. 2010, 76, 463-475. [CrossRef]

28. Burley, J.; Ebeling, J.; Costa, P.; Freer-Smith, P.; Broadmeadow, M.; Lynch, J. 5 Carbon sequestration as a forestry opportunity in a changing climate. In Forestry and Climate Change; CABI: Oxfordshire, UK, 2007; p. 31.

29. Bastin, J.-F.; Finegold, Y.; Garcia, C.; Mollicone, D.; Rezende, M.; Routh, D.; Zohner, C.M.; Crowther, T.W. The global tree restoration potential. Science 2019, 365, 76-79. [CrossRef]

30. Cacho, O.J.; Marshall, G.R.; Milne, M. Transaction and abatement costs of carbon-sink projects in developing countries. Environ. Dev. Econ. 2005, 10, 597-614. [CrossRef]

31. Wunder, S. Payments for Environmental Services: Some Nuts and Bolts; CIFOR Occasional Paper No. 42; Center for International Forestry Research: Bogor, Indonesia, 2005.

32. Laurance, W.F. A crisis in the making: Responses of Amazonian forests to land use and climate change. Trends Ecol. Evol. 1998, 13, 411-415. [CrossRef]

33. Kirschbaum, M.U.F. Can Trees Buy Time? An Assessment of the Role of Vegetation Sinks as Part of the Global Carbon Cycle. Clim. Chang. 2003, 58, 47-71. [CrossRef]

34. Grace, J. Understanding and managing the global carbon cycle. J. Ecol. 2004, 92, 189-202. [CrossRef]

35. Le, H.D.; Smith, C.; Herbohn, J. What drives the success of reforestation projects in tropical developing countries? The case of the Philippines. Glob. Environ. Chang. 2014, 24, 334-348. [CrossRef]

36. Ravindranath, N.; Chaturvedi, R.K.; Murthy, I.K. Forest conservation, afforestation and reforestation in India: Implications for forest carbon stocks. Curr. Sci. 2008, 216-222.

37. De Jesus, R.M. The need for reforestation. In Proceedings of the International Workshop on Large-Scale Reforestation, Corvallis, Oregon, 9-10 May 1990; p. 81.

38. Jindal, R.; Swallow, B.; Kerr, J. Forestry-based carbon sequestration projects in Africa: Potential benefits and challenges. Nat. Resour. Forum 2008, 32, 116-130. [CrossRef]

39. Reynolds, T.W. Institutional Determinants of Success among Forestry-Based Carbon Sequestration Projects in Sub-Saharan Africa. World Dev. 2012, 40, 542-554. [CrossRef]

40. McLymont, R. Toward Clean and Green. Network J. 2010, 17, 20.

41. Reid, H. Climate change and biodiversity in Europe. Conserv. Soc. 2006, 4, 84.

42. Curiel-Esparza, J.; Gonzalez-Utrillas, N.; Canto-Perello, J.; Martin-Utrillas, M. Integrating climate change criteria in reforestation projects using a hybrid decision-support system. Environ. Res. Lett. 2015, 10, 94022. [CrossRef]

43. Ivetić, V.; Devetaković, J. Reforestation challenges in Southeast Europe facing climate change. REFORESTA 2016, 1, 178-220. [CrossRef]

44. Lopes, J.A.; Santos, M. Facilitating Financing for Sustainable Forest Management in Small Islands Developing States and Low Forest Cover Countries; An analytical report prepared by Indufor for the United Nations Forum on Forests; Country Case Study: Helsinki, Finland, August 2010; 27p.

45. Nijnik, M.; Bizikova, L. Responding to the Kyoto Protocol through forestry: A comparison of opportunities for several countries in Europe. For. Policy Econ. 2008, 10, 257-269. [CrossRef] 
46. Olschewski, R.; Benítez, P.C. Optimizing joint production of timber and carbon sequestration of afforestation projects. J. For. Econ. 2010, 16, 1-10. [CrossRef]

47. Major, I.; Haszpra, L.; Rinyu, L.; Futó, I.; Bihari, Á.; Hammer, S.; Jull, A.J.T.; Molnár, M. Temporal Variation of Atmospheric Fossil and Modern $\mathrm{CO}_{2}$ Excess at a Central European Rural Tower Station between 2008 and 2014. Radiocarb. 2018, 60, 1285-1299. [CrossRef]

48. Möller, D.; Oelßner, W. Environmental $\mathrm{CO}_{2}$ monitoring. In Carbon Dioxide Sensing: Fundamentals, Principles, and Applications; John Wiley \& Sons: Hoboken, NJ, USA, 2019; p. 275.

49. Peñuelas, J.; Sardans, J.; Estiarte, M.; Ogaya, R.; Carnicer, J.; Coll, M.; Barbeta, A.; Rivas-Ubach, A.; Llusià, J.; Garbulsky, M.; et al. Evidence of current impact of climate change on life: A walk from genes to the biosphere. Glob. Chang. Boil. 2013, 19, 2303-2338. [CrossRef]

50. Van Aalst, M.K. The impacts of climate change on the risk of natural disasters. Disasters 2006, 30, 5-18. [CrossRef]

51. Pachauri, R.K.; Reisinger, A. IPCC Fourth Assessment Report; IPCC: Geneva, Switzerland, 2007.

52. Bogner, J.; Pipatti, R.; Hashimoto, S.; Diaz, C.; Mareckova, K.; Diaz, L.; Kjeldsen, P.; Monni, S.; Faaij, A.; Gao, Q.; et al. Mitigation of global greenhouse gas emissions from waste: Conclusions and strategies from the Intergovernmental Panel on Climate Change (IPCC) Fourth Assessment Report. Working Group III (Mitigation). Waste Manag. Res. 2008, 26, 11-32. [CrossRef] [PubMed]

53. Keeling, C.D.; Bacastow, R.B.; Bainbridge, A.E.; Ekdahl, C.A., Jr.; Guenther, P.R.; Waterman, L.S.; Chin, J.F. Atmospheric carbon dioxide variations at Mauna Loa observatory, Hawaii. Tellus 1976, 28, 538-551.

54. Stocker, T.F.; Qin, D.; Plattner, G.K.; Tignor, M.; Allen, S.K.; Boschung, J.; Nauels, A.; Xia, Y.; Bex, V.; Midgley, P.M. Climate Change 2013: The Physical Science Basis; IPCC: Geneva, Switzerland, 2013.

55. Etheridge, D.M.; Steele, L.P.; Langenfelds, R.L.; Francey, R.J.; Barnola, J.-M.; Morgan, V.I. Natural and anthropogenic changes in atmospheric $\mathrm{CO}_{2}$ over the last 1000 years from air in Antarctic ice and firn. J. Geophys. Res. Space Phys. 1996, 101, 4115-4128. [CrossRef]

56. Pearman, G.I.; Etheridge, D.; De Silva, F.; Fraser, P.J. Evidence of changing concentrations of atmospheric $\mathrm{CO}_{2}, \mathrm{~N} 2 \mathrm{O}$ and $\mathrm{CH} 4$ from air bubbles in Antarctic ice. Nature 1986, 320, 248-250. [CrossRef]

57. Barnola, J.M.; Pimienta, P.; Raynaud, D.; Korotkevich, Y.S. $\mathrm{CO}_{2}$-climate relationship as deduced from the Vostok ice core: A re-examination based on new measurements and on a re-evaluation of the air dating. Tellus B 1991, 43, 83-90. [CrossRef]

58. Seinfeld, J.H.; Pandis, S.N. Atmospheric Chemistry and Physics: From Air Pollution to Climate Change; John Wiley \& Sons: Hoboken, NJ, USA, 2016.

59. Sun, Y.; Frankenberg, C.; Wood, J.D.; Schimel, D.S.; Jung, M.; Guanter, L.; Drewry, D.T.; Verma, M.; Porcar-Castell, A.; Griffis, T.J.; et al. OCO-2 advances photosynthesis observation from space via solar-induced chlorophyll fluorescence. Science 2017, 358, eaam5747. [CrossRef] [PubMed]

60. Liu, Y.; Yang, D.; Cai, Z. A retrieval algorithm for TanSat $\mathrm{XCO}_{2}$ observation: Retrieval experiments using GOSAT data. Chin. Sci. Bull. 2013, 58, 1520-1523. [CrossRef]

61. Butz, A.; Guerlet, S.; Hasekamp, O.; Schepers, D.; Galli, A.; Aben, I.; Frankenberg, C.; Hartmann, J.-M.; Tran, H.; Kuze, A.; et al. Toward accurate $\mathrm{CO}_{2}$ and $\mathrm{CH} 4$ observations from GOSAT. Geophys. Res. Lett. 2011, 38, 38. [CrossRef]

62. Taylor, T.E.; O'dell, C.W.; Frankenberg, C.; Partain, P.T.; Cronk, H.Q.; Savtchenko, A.; Nelson, R.R.; Rosenthal, E.J.; Chang, A.Y.; Fisher, B.; et al. Orbiting Carbon Observatory-2 (OCO-2) cloud screening algorithms: Validation against collocated MODIS and CALIOP data. Atmospheric Meas. Tech. 2016, 9, 973-989. [CrossRef]

63. Canadell, J.G.; Ciais, P.; Gurney, K.; Le Quéré, C.; Piao, S.; Raupach, M.R.; Sabine, C.L. An International Effort to Quantify Regional Carbon Fluxes. Eos 2011, 92, 81-82. [CrossRef]

64. Sitch, S.; Friedlingstein, P.; Gruber, N.; Jones, S.D.; Murray-Tortarolo, G.; Ahlström, A.; Doney, S.C.; Graven, H.; Heinze, C.; Huntingford, C.; et al. Recent trends and drivers of regional sources and sinks of carbon dioxide. Biogeosciences 2015, 12, 653-679. [CrossRef]

65. Peylin, P.; Law, R.; Gurney, K.; Chevallier, F.; Jacobson, A.; Maki, T.; Niwa, Y.; Patra, P.; Peters, W.; Rayner, P. Global atmospheric carbon budget: Results from an ensemble of atmospheric $\mathrm{CO}_{2}$ inversions. Biogeosciences 2013, 10, 6699-6720. [CrossRef]

66. Allam, S.; D EL Ouadghiri, M.; EL Ouahbi, R. Carbon Dioxide Information Analysis Center CDIAC: Databases analysis (December 2015). Adv. Inf. Technol. Theory Appl. 2016,1. Available online: https://cdiac.ess-dive.lbl.gov/ (accessed on 3 December 2019). 
67. Moberg, R.; Stewart, D.; Stachniak, D. The IEA Weyburn $\mathrm{CO}_{2}$ Monitoring and Storage Project. In Greenhouse Gas Control Technologies—6th International Conference; Elsevier BV: Amsterdam, The Netherlands, 2003; pp. 219-224.

68. McDonald, R.I.; Fargione, J.; Kiesecker, J.; Miller, W.M.; Powell, J. Energy Sprawl or Energy Efficiency: Climate Policy Impacts on Natural Habitat for the United States of America. PLoS ONE 2009, 4, e6802. [CrossRef] [PubMed]

69. Houghton, R.A.; House, J.; Pongratz, J.; Van Der Werf, G.; DeFries, R.; Hansen, M.; Quéré, C.L.; Ramankutty, N. Carbon emissions from land use and land-cover change. Biogeosciences 2012, 9, 5125-5142. [CrossRef]

70. Le Quéré, C.; Moriarty, R.; Andrew, R.M.; Peters, G.P.; Ciais, P.; Friedlingstein, P.; Jones, S.D.; Sitch, S.; Tans, P.; Arneth, A.; et al. Global carbon budget 2014. Earth Syst. Sci. Data 2015, 7, 47-85. [CrossRef]

71. Bustamante, M.; Robledo-Abad, C.; Harper, R.; Mbow, C.; Ravindranat, N.H.; Sperling, F.; Haberl, H.; Pinto, A.D.S.; Smith, P. Co-benefits, trade-offs, barriers and policies for greenhouse gas mitigation in the agriculture, forestry and other land use (AFOLU) sector. Glob. Chang. Boil. 2014, 20, 3270-3290. [CrossRef]

72. McKinley, G.A.; Fay, A.R.; Takahashi, T.; Metzl, N. Convergence of atmospheric and North Atlantic carbon dioxide trends on multidecadal timescales. Nat. Geosci. 2011, 4, 606-610. [CrossRef]

73. Le Quéré, C.; Moriarty, R.; Andrew, R.M.; Canadell, J.G.; Sitch, S.; Korsbakken, J.I.; Friedlingstein, P.; Peters, G.P.; Andres, R.J.; Boden, T.A.; et al. Global Carbon Budget 2015. Earth Syst. Sci. Data 2015, 7, 349-396. [CrossRef]

74. Le Quéré, C.; Andrew, R.M.; Canadell, J.G.; Sitch, S. Global carbon budget 2016. Earth Syst. Sci. Data 2016, 8, 605-649. [CrossRef]

75. Fay, A.; McKinley, G. Global trends in surface ocean $\mathrm{pCO}_{2}$ from in situ data. Glob. Biogeochem. Cycles 2013, 27, 541-557. [CrossRef]

76. Post, W.M.; Peng, T.-H.; Emanuel, W.R.; King, A.W.; Dale, V.H.; DeAngelis, D.L. The global carbon cycle. Am. Sci. 1990, 78, 310-326.

77. Neff, J.C.; Asner, G.P. Dissolved Organic Carbon in Terrestrial Ecosystems: Synthesis and a Model. Ecosystems 2001, 4, 29-48. [CrossRef]

78. Baldocchi, D.; Valentini, R.; Running, S.; Oechel, W.; Dahlman, R. Strategies for measuring and modelling carbon dioxide and water vapour fluxes over terrestrial ecosystems. Glob. Chang. Boil. 1996, 2, 159-168. [CrossRef]

79. Baldocchi, D.; Falge, E.; Gu, L.; Olson, R.; Hollinger, D.; Running, S.; Anthoni, P.; Bernhofer, C.; Davis, K.; Evans, R. FLUXNET: A new tool to study the temporal and spatial variability of ecosystem-scale carbon dioxide, water vapor, and energy flux densities. Bull. Am. Meteorol. Soc. 2001, 82, 2415-2434. [CrossRef]

80. Baldocchi, D. 'Breathing' of the terrestrial biosphere: Lessons learned from a global network of carbon dioxide flux measurement systems. Aust. J. Bot. 2008, 56, 1-26. [CrossRef]

81. U.S. Department of Energy. About the FLUXDATA Network. Available online: https://fluxnet.fluxdata.org/ about/ (accessed on 27 November 2019).

82. Vitousek, P.M. Global environmental change: An introduction. Annu. Rev. Ecol. Syst. 1992, 23, 1-14. [CrossRef]

83. Vitousek, P.M. Beyond global warming: Ecology and global change. Ecology 1994, 75, 1861-1876. [CrossRef]

84. Vitousek, P.M.; D'Antonio, C.M.; Loope, L.L.; Westbrooks, R. Biological invasions as global environmental change. Am. Sci. 1996, 84, 468-478.

85. Vitousek, P.M.; D’antonio, C.M.; Loope, L.L.; Rejmanek, M.; Westbrooks, R. Introduced species: A significant component of human-caused global change. N. Z. J. Ecol. 1997, 21, 1-16.

86. Henry, H.A.L.; Juarez, J.D.; Field, C.B.; Vitousek, P.M. Interactive effects of elevated $\mathrm{CO}_{2}, \mathrm{~N}$ deposition and climate change on extracellular enzyme activity and soil density fractionation in a California annual grassland. Glob. Chang. Boil. 2005, 11, 1808-1815. [CrossRef]

87. Vitousek, S.; Barnard, P.L.; Limber, P.; Erikson, L.; Cole, B. A model integrating longshore and cross-shore processes for predicting long-term shoreline response to climate change. J. Geophys. Res. Earth Surf. 2017, 122, 782-806. [CrossRef]

88. De Noblet-Ducoudré, N.; Boisier, J.-P.; Pitman, A.; Bonan, G.B.; Brovkin, V.; Cruz, F.; Delire, C.; Gayler, V.; Hurk, B.J.J.M.V.D.; Lawrence, P.J.; et al. Determining Robust Impacts of Land-Use-Induced Land Cover Changes on Surface Climate over North America and Eurasia: Results from the First Set of LUCID Experiments. J. Clim. 2012, 25, 3261-3281. [CrossRef] 
89. Bonan, G.B. Forests and Climate Change: Forcings, Feedbacks, and the Climate Benefits of Forests. Science 2008, 320, 1444-1449. [CrossRef] [PubMed]

90. Oleson, K.W.; Bonan, G.B.; Feddema, J.; Vertenstein, M.; Grimmond, C.S.B. An Urban Parameterization for a Global Climate Model. Part I: Formulation and Evaluation for Two Cities. J. Appl. Meteorol. Clim. 2008, 47, 1038-1060. [CrossRef]

91. Jackson, R.B.; Canadell, J.G.; Avissar, R.; Baldocchi, D.D.; Bonan, G.B.; Caldeira, K.; Diffenbaugh, N.S.; Field, C.B.; A Hungate, B.; Jobbágy, E.G.; et al. Protecting climate with forests. Environ. Res. Lett. 2008, 3, 044006. [CrossRef]

92. Ridgwell, A.; Zeebe, R. The role of the global carbonate cycle in the regulation and evolution of the Earth system. Earth Planet. Sci. Lett. 2005, 234, 299-315. [CrossRef]

93. Kump, L.R.; Brantley, S.L.; Arthur, M.A. Chemical Weathering, Atmospheric $\mathrm{CO}_{2}$, and Climate. Annu. Rev. Earth Planet. Sci. 2000, 28, 611-667. [CrossRef]

94. Martin, J.B. Carbonate minerals in the global carbon cycle. Chem. Geol. 2017, 449, 58-72. [CrossRef]

95. Adams, H.D.; Macalady, A.K.; Breshears, D.D.; Allen, C.D.; Stephenson, N.L.; Saleska, S.R.; Huxman, T.E.; McDowell, N.G. Climate-Induced Tree Mortality: Earth System Consequences. Eos 2010, 91, 153. [CrossRef]

96. Bonan, G. Ecological Climatology: Concepts and Applications; Cambridge University Press: Cambridge, UK, 2015.

97. Allen, C.D.; Macalady, A.K.; Chenchouni, H.; Bachelet, M.; McDowell, N.; Vennetier, M.; Kitzberger, T.; Rigling, A.; Breshears, D.D.; Hogg, E.H.; et al. A global overview of drought and heat-induced tree mortality reveals emerging climate change risks for forests. For. Ecol. Manag. 2010, 259, 660-684. [CrossRef]

98. Graybill, D.A.; Idso, S.B. Detecting the aerial fertilization effect of atmospheric $\mathrm{CO}_{2}$ enrichment in tree-ring chronologies. Glob. Biogeochem. Cycles 1993, 7, 81-95. [CrossRef]

99. Wullschleger, S.D.; Post, W.; King, A. On the potential for a $\mathrm{CO}_{2}$ fertilization effect in forests: Estimates of the biotic growth factor based on 58 controlled-exposure studies. In Biotic Feedbacks in the Global Climatic System; Woodwell, G.M., Mackenzie, F.T., Eds.; Oxford University Press: Oxford, UK, 1995; pp. 85-107.

100. Cao, M.; Woodward, F.I. Net primary and ecosystem production and carbon stocks of terrestrial ecosystems and their responses to climate change. Glob. Chang. Boil. 1998, 4, 185-198. [CrossRef]

101. Seneviratne, S.I.; Corti, T.; Davin, E.L.; Hirschi, M.; Jaeger, E.B.; Lehner, I.; Orlowsky, B.; Teuling, A.J. Investigating soil moisture-climate interactions in a changing climate: A review. Earth-Science Rev. 2010, 99, 125-161. [CrossRef]

102. Van Mantgem, P.J.; Stephenson, N.L.; Byrne, J.C.; Daniels, L.D.; Franklin, J.F.; Fulé, P.Z.; Harmon, M.E.; Larson, A.J.; Smith, J.M.; Taylor, A.H.; et al. Widespread Increase of Tree Mortality Rates in the Western United States. Science 2009, 323, 521-524. [CrossRef]

103. Broecker, W.S.; Takahashi, T.; Simpson, H.J.; Peng, T.-H. Fate of Fossil Fuel Carbon Dioxide and the Global Carbon Budget. Science 1979, 206, 409-418. [CrossRef]

104. Revelle, R.; Suess, H.E. Carbon Dioxide Exchange Between Atmosphere and Ocean and the Question of an Increase of Atmospheric $\mathrm{CO}_{2}$ during the Past Decades. Tellus 1957, 9, 18-27. [CrossRef]

105. Yuan-Hui, L. Geochemical cycles of elements and human perturbation. Geochim. et Cosmochim. Acta 1981, 45, 2073-2084. [CrossRef]

106. NOAA. Atmospheric Carbon Dioxide Concentrations and Global Annual Average Temperatures over the Years 1880 to 2009. Available online: https://ja.wikipedia.org/wiki/\%E3\%83\%95\%E3\%82\%A1\%E3\%82\%A4\% E3\%83\%AB:Atmospheric_carbon_dioxide_concentrations_and_global_annual_average_temperatures_ over_the_years_1880_to_2009.png (accessed on 25 August 2018).

107. Trenberth, K.E.; Stepaniak, D.P. The flow of energy through the earth's climate system. Q. J. R. Meteorol. Soc. 2004, 130, 2677-2701. [CrossRef]

108. Ramanathan, V.; Barkstrom, B.R.; Harrison, E.F. Climate and the Earth's Radiation Budget. Phys. Today 1989, 42, 22. [CrossRef]

109. Pecl, G.T.; Araújo, M.B.; Bell, J.D.; Blanchard, J.; Bonebrake, T.C.; Chen, I.-C.; Clark, T.D.; Colwell, R.K.; Danielsen, F.; Evengård, B.; et al. Biodiversity redistribution under climate change: Impacts on ecosystems and human well-being. Science 2017, 355, eaai9214. [CrossRef]

110. Perlack, R.D.; Wright, L.L.; Turhollow, A.F.; Graham, R.L.; Stokes, B.J.; Erbach, D.C. Biomass as Feedstock for a Bioenergy and Bioproducts Industry: The Technical Feasibility of a Billion-Ton Annual Supply; Oak Ridge National Laboratory: Oak Ridge, TN, USA, 2005. 
111. Nair, P.K.R.; Kumar, B.M.; Nair, V.D. Agroforestry as a strategy for carbon sequestration. J. Plant Nutr. Soil Sci. 2009, 172, 10-23. [CrossRef]

112. Fang, J.; Chen, A.; Peng, C.; Zhao, S.; Ci, L. Changes in Forest Biomass Carbon Storage in China Between 1949 and 1998. Science 2001, 292, 2320-2322. [CrossRef] [PubMed]

113. Nowak, D.J.; Crane, D.E. Carbon storage and sequestration by urban trees in the USA. Environ. Pollut. 2002, 116, 381-389. [CrossRef]

114. Nelson, E.; Polasky, S.; Lewis, D.J.; Plantinga, A.J.; Lonsdorf, E.; White, D.; Bael, D.; Lawler, J.J. Efficiency of incentives to jointly increase carbon sequestration and species conservation on a landscape. Proc. Natl. Acad. Sci. USA 2008, 105, 9471-9476.

115. Alvarez, R. A review of nitrogen fertilizer and conservation tillage effects on soil organic carbon storage. Soil Use Manag. 2005, 21, 38-52. [CrossRef]

116. Pękala, Ł.M.; Tan, R.R.; Foo, D.C.; Jeżowski, J.M. Optimal energy planning models with carbon footprint constraints. Appl. Energy 2010, 87, 1903-1910. [CrossRef]

117. Luyssaert, S.; Schulze, E.-D.; Börner, A.; Knohl, A.; Hessenmöller, D.; Law, B.E.; Ciais, P.; Grace, J. Old-growth forests as global carbon sinks. Nature 2008, 455, 213-215. [CrossRef]

118. Lewis, S.L.; Lopez-Gonzalez, G.; Sonké, B.; Affum-Baffoe, K.; Baker, T.R.; Ojo, L.O.; Phillips, O.L.; Reitsma, J.M.; White, L.; Comiskey, J.A.; et al. Increasing carbon storage in intact African tropical forests. Nature 2009, 457, 1003-1006. [CrossRef]

119. Mackey, B.; Prentice, I.C.; Steffen, W.; House, J.I.; Lindenmayer, D.; Keith, H.; Berry, S. Untangling the confusion around land carbon science and climate change mitigation policy. Nat. Clim. Chang. 2013, 3, 552-557. [CrossRef]

120. Körner, C. A matter of tree longevity. Science 2017, 355, 130-131. [CrossRef]

121. Griscom, B.W.; Adams, J.; Ellis, P.W.; Houghton, R.A.; Lomax, G.; Miteva, D.A.; Schlesinger, W.H.; Shoch, D.; Siikamäki, J.V.; Smith, P.; et al. Natural climate solutions. Proc. Natl. Acad. Sci. USA 2017, 114, 11645-11650.

122. Kirschbaum, M.U. To sink or burn? A discussion of the potential contributions of forests to greenhouse gas balances through storing carbon or providing biofuels. Biomass Bioenergy 2003, 24, 297-310. [CrossRef]

123. Asner, G.P.; Powell, G.V.N.; Mascaro, J.; Knapp, D.E.; Clark, J.K.; Jacobson, J.; Kennedy-Bowdoin, T.; Balaji, A.; Paez-Acosta, G.; Victoria, E.; et al. High-resolution forest carbon stocks and emissions in the Amazon. Proc. Natl. Acad. Sci. USA 2010, 107, 16738-16742.

124. Pearson, T.R.H.; Brown, S.; Murray, L.; Sidman, G. Greenhouse gas emissions from tropical forest degradation: An underestimated source. Carbon Balance Manag. 2017, 12, 3. [CrossRef] [PubMed]

125. Putz, F.E.; Zuidema, P.A.; Synnott, T.; Peña-Claros, M.; Pinard, M.A.; Sheil, D.; Vanclay, J.K.; Sist, P.; Gourlet-Fleury, S.; Griscom, B.; et al. Sustaining conservation values in selectively logged tropical forests: The attained and the attainable. Conserv. Lett. 2012, 5, 296-303. [CrossRef]

126. Dean, C.; Wardell-Johnson, G.W.; Kirkpatrick, J.B. Are there any circumstances in which logging primary wet-eucalypt forest will not add to the global carbon burden? Agric. For. Meteorol. 2012, 161, 156-169. [CrossRef]

127. Bryan, J.; Shearman, P.; Ash, J.; Kirkpatrick, J.B. Impact of logging on aboveground biomass stocks in lowland rain forest, Papua New Guinea. Ecol. Appl. 2010, 20, 2096-2103. [CrossRef] [PubMed]

128. Körner, C. ATMOSPHERIC SCIENCE: Slow in, Rapid out-Carbon Flux Studies and Kyoto Targets. Science 2003, 300, 1242-1243. [CrossRef] [PubMed]

129. Moomaw, W.R.; Masino, S.A.; Faison, E.K. Intact Forests in the United States: Proforestation Mitigates Climate Change and Serves the Greatest Good. Front. For. Glob. Chang. 2019, 2, 27. [CrossRef]

130. Dixon, R.K.; Solomon, A.M.; Brown, S.; Houghton, R.A.; Trexier, M.C.; Wiśniewski, J. Carbon Pools and Flux of Global Forest Ecosystems. Science 1994, 263, 185-190. [CrossRef]

131. Carle, J.; Holmgren, P. Wood from planted forests. For. Prod. J. 2008, 58, 6.

132. Zhang, H.; Guan, D.; Song, M. Biomass and carbon storage of Eucalyptus and Acacia plantations in the Pearl River Delta, South China. For. Ecol. Manag. 2012, 277, 90-97. [CrossRef]

133. Giardina, C.P.; Ryan, M.G. Total Belowground Carbon Allocation in a Fast-growing Eucalyptus Plantation Estimated Using a Carbon Balance Approach. Ecosystems 2002, 5, 487-499. [CrossRef]

134. Keith, H.; MacKey, B.G.; Lindenmayer, D.B. Re-evaluation of forest biomass carbon stocks and lessons from the world's most carbon-dense forests. Proc. Natl. Acad. Sci. USA 2009, 106, 11635-11640. [CrossRef] [PubMed]

135. Liski, J.; Pussinen, A.; Pingoud, K.; Mäkipää, R.; Karjalainen, T. Which rotation length is favourable to carbon sequestration? Can. J. For. Res. 2001, 31, 2004-2013. [CrossRef] 
136. Brown, S. Bosques y Cambio Climático y la Función de Los Bosques Como Sumideros de Carbono. 1997. Available online: https://www.typsa.com/files/pdf/Bosques.pdf (accessed on 3 December 2019).

137. Cox, P.M.; Betts, R.A.; Jones, C.D.; Spall, S.A.; Totterdell, I.J. Acceleration of global warming due to carbon-cycle feedbacks in a coupled climate model. Nature 2000, 408, 184-187. [CrossRef]

138. Cooper, C.F. Carbon storage in managed forests. Can. J. For. Res. 1983, 13, 155-166. [CrossRef]

139. Harmon, M.E.; Ferrell, W.K.; Franklin, J.F. Effects on carbon storage of conversion of old-growth forests to young forests. Science 1990, 247, 699-702. [CrossRef]

140. Sohngen, B.; Mendelsohn, R. An Optimal Control Model of Forest Carbon Sequestration. Am. J. Agric. Econ. 2003, 85, 448-457. [CrossRef]

141. Palma, J.H.N.; Paulo, J.A.; Tomé, M. Carbon sequestration of modern Quercus suber L. silvoarable agroforestry systems in Portugal: A YieldSAFE-based estimation. Agrofor. Syst. 2014, 88, 791-801. [CrossRef]

142. Ogaya, R.; Peñuelas, J. Tree growth, mortality, and above-ground biomass accumulation in a holm oak forest under a five-year experimental field drought. Plant Ecol. 2007, 189, 291-299. [CrossRef]

143. Marland, G.; Schlamadinger, B. Forests for carbon sequestration or fossil fuel substitution? A sensitivity analysis. Biomass Bioenergy 1997, 13, 389-397. [CrossRef]

144. Perez-Garcia, J.; Lippke, B.; Comnick, J.; Manriquez, C. An assessment of carbon pools, storage, and wood products market substitution using life-cycle analysis results. Wood Fiber Sci. 2007, 37, 140-148.

145. Chulze, E.-D.; Körner, C.; Law, B.E.; Haberl, H.; Luyssaert, S. Large-scale bioenergy from additional harvest of forest biomass is neither sustainable nor greenhouse gas neutral. GCB Bioenergy 2012, 4, 611-616. [CrossRef]

146. Gustavsson, L.; Haus, S.; Lundblad, M.; Lundström, A.; Ortiz, C.A.; Sathre, R.; Le Truong, N.; Wikberg, P.-E. Climate change effects of forestry and substitution of carbon-intensive materials and fossil fuels. Renew. Sustain. Energy Rev. 2017, 67, 612-624. [CrossRef]

147. Baral, A. Trees for carbon sequestration or fossil fuel substitution: The issue of cost vs. carbon benefit. Biomass Bioenergy 2004, 27, 41-55. [CrossRef]

148. Bird, D.N. Estimating the Displacement of Energy and Materials by Woody Biomass in Austria; Joanneum Research Resources: Graz, Austria, 2013.

149. Ingerson, A. Carbon storage potential of harvested wood: Summary and policy implications. Mitigation Adapt. Strateg. Glob. Chang. 2011, 16, 307-323. [CrossRef]

150. E Harmon, M. Have product substitution carbon benefits been overestimated? A sensitivity analysis of key assumptions. Environ. Res. Lett. 2019, 14, 065008. [CrossRef]

151. Marras, T.; Petroselli, A.; Vessella, F.; Damiani, G.; Schirone, B. Noble biomass: Restore, recycle, profit using cork oak (Quercus suber L.). Appl. Math. Sci. 2014, 8, 6495-6513. [CrossRef]

152. Aronson, J.; Santos-Pereira, J.; Pausas, J.G. (Eds.) Cork Oak Woodlands on the Edge: Ecology, Adaptive Management, and Restoration; Island Press: Washington, DC, USA, 2009; pp. 1-10.

153. A Coomes, D.; Allen, R.B.; A Scott, N.; Goulding, C.; Beets, P. Designing systems to monitor carbon stocks in forests and shrublands. For. Ecol. Manag. 2002, 164, 89-108. [CrossRef]

154. Zylstra, P.J. Flammability dynamics in the Australian Alps. Austral Ecol. 2018, 43, 578-591. [CrossRef]

155. Taylor, C.; McCarthy, M.A.; Lindenmayer, D.B. Nonlinear Effects of Stand Age on Fire Severity. Conserv. Lett. 2014, 7, 355-370. [CrossRef]

156. Lohmann, L. Carbon trading. Dev. Dialogue 2006, 48, 1-359.

(C) 2020 by the authors. Licensee MDPI, Basel, Switzerland. This article is an open access article distributed under the terms and conditions of the Creative Commons Attribution (CC BY) license (http://creativecommons.org/licenses/by/4.0/). 